\title{
An overview of current applications, challenges, and future trends in distributed process-based models in hydrology
}

Simone Fatichi ${ }^{1}$, Enrique R. Vivoni ${ }^{2}$, Fred L. Ogden ${ }^{3}$, Valeriy Y. Ivanov ${ }^{4}$, Benjamin Mirus ${ }^{5}$, David Gochis $^{6}$, Charles W. Downer ${ }^{7}$, Matteo Camporese ${ }^{8}$, Jason H. Davison ${ }^{9}$, Brian Ebel ${ }^{10}$, Norm Jones ${ }^{11}$, Jongho Kim ${ }^{4}$, Giuseppe Mascaro ${ }^{12}$, Richard Niswonger ${ }^{13}$, Pedro Restrepo ${ }^{14}$, Riccardo Rigon ${ }^{15}$, Chaopeng Shen ${ }^{16}$, Mauro Sulis ${ }^{17}$, and David Tarboton ${ }^{18}$

\author{
${ }^{1}$ Institute of Environmental Engineering, ETH Zurich, Zurich, Switzerland \\ ${ }^{2}$ School of Earth and Space Exploration \& School of Sustainable Engineering and the Built \\ Environment, Arizona State University, Tempe, Arizona, USA \\ ${ }^{3}$ Department of Civil \& Architectural Engineering. University of Wyoming, Laramie, \\ Wyoming, USA \\ ${ }^{4}$ Department of Civil and Environmental Engineering, University of Michigan, Ann Arbor, \\ MI, USA \\ ${ }^{5}$ U.S. Geological Survey, Geologic Hazards Science Center, Golden, CO, USA \\ ${ }^{6}$ National Center for Atmospheric Research, Boulder, Colorado USA \\ ${ }^{7}$ Hydrologic Systems Branch, Coastal and Hydraulic Laboratory, Engineer Research and \\ Development Center, Vicksburg, Mississippi, USA \\ ${ }^{8}$ Department of Civil, Environmental and Architectural Engineering, University of Padua, \\ Padua, Italy \\ ${ }^{9}$ Department of Earth and Environmental Sciences, University of Waterloo, Waterloo, \\ Ontario, Canada \\ ${ }^{10}$ U.S. Geological Survey, National Research Program, Denver, CO, USA \\ ${ }^{11}$ Brigham Young University, Provo, Utah, USA \\ ${ }^{12}$ Julie Anne Wrigley Global Institute of Sustainability, Arizona State University, Tempe, \\ AZ, USA \\ ${ }^{13}$ U.S. Geological Survey National Research Program, Menlo Park, CA, USA \\ ${ }^{14}$ North Central River Forecast Center, NOAA National Weather Service, Chanhassen, MN \\ USA \\ ${ }^{15}$ Dipartimento di Ingegneria Civile, Ambientale e Meccanica e CUDAM, Università di \\ Trento, Trento, Italy \\ ${ }^{16}$ Department of Civil and Environmental Engineering, Pennsylvania State University, \\ University Park, Pennsylvania, USA. \\ ${ }^{17}$ Meteorological Institute, University of Bonn, Bonn, Germany \\ ${ }^{18}$ Civil and Environmental Engineering, Utah State University, Logan, UT, USA
}

*DISCLAIMER: This draft manuscript is distributed solely for purposes of scientific peer review. Its content is deliberative and predecisional, so it must not be disclosed or released by reviewers. Because the manuscript has not yet been approved for publication by the U.S. Geological Survey (USGS), it does not represent any official USGS finding or policy. 
Corresponding author: Simone Fatichi, Institute of Environmental Engineering, ETH Zurich, Switzerland Stefano Franscini-Platz 5, HIL D 23.2, 8093 Zurich, Switzerland

Tel.: +41-44-6324118, Fax: +41-44-3331539

simone.fatichi@ifu.baug.ethz.ch

\section{Submitted revised version to Journal of Hydrology}

[8 February 2016]

\section{Abstract}

Process-based hydrological models have a long history dating back to the 1960s. Criticized by some as over-parameterized, overly complex, and difficult to use, a more nuanced view is that these tools are necessary in many situations and, in a certain class of problems, they are the most appropriate type of hydrological model. This is especially the case in situations where knowledge of flow paths or distributed state variables and/or preservation of physical constraints is important. Examples of this include: spatiotemporal variability of soil moisture, groundwater flow and runoff generation, sediment and contaminant transport, or when feedbacks among various Earth's system processes or understanding the impacts of climate non-stationarity are of primary concern. These are situations where process-based models excel and other models are unverifiable. This article presents this pragmatic view in the context of existing literature to justify the approach where applicable and necessary. We review how improvements in data availability, computational resources and algorithms have made detailed hydrological simulations a reality. Avenues for the future of process-based hydrological models are presented suggesting their use as virtual laboratories, for design purposes, and with a powerful treatment of uncertainty.

Keywords: modeling, interdisciplinary, watershed processes, virtual experiments, change assessments, natural and built environment. 


\section{Introduction}

The development of process-based watershed models based on the concepts of observability and scalability of physical hydrological processes has roots that go back almost fifty years with the works of Crawford and Linsley (1966) and Freeze and Harlan (1969). Despite the success of the approach in subsequent decades (e.g., Stephenson and Freeze 1974, Abbott et al. 1986), initial optimism has increasingly been challenged by the scientific community (e.g., Beven 1989). The idea that a mathematical model can provide accurate results across different climates, watersheds, and hydrological extreme conditions based on physical laws and parameters determined a priori has been considered a "Hydrologic El Dorado" or an unachievable goal (Woolhiser 1996, Grayson et al. 1992). Furthermore, the challenges imposed by hydrological process non-linearity, temporal and spatial scale dependence, system observability and heterogeneity, and parameter equifinality, among other issues, have led to questioning the usefulness of the approach (e.g., Beven 1989, 2001, Beven and Cloke 2012) and to proposals of alternatives (e.g., Beven 2002, Sivapalan 2003, McDonnell et al. 2007, Wagener et al. 2007, Troch et al. 2008, Clark et al. 2011).

Concurrently, hydrology has gained a broad, international recognition as a geoscience moving from an appendix of textbooks on hydraulics and geology (Klemes 1986, 1988, Bras and Eagleson 1987) to a cornerstone discipline in the geosciences (Bras 2009). Process-based watershed modeling has played an important role in this development, in particular for interdisciplinary efforts such as ecohydrology, geomorphology, cryospheric science, and land-atmosphere interactions (e.g., Bras et al. 2003, Ebel and Loague 2006, Loague et al. 2006, Rigon et al. 2006, Maxwell et al. 2007, Ivanov et. al. 2008a, Yetemen et al. 2015). Process-based modeling approaches are also believed to help provide predictions under a non-stationary climate (Huntington and Niswonger 2012, Sulis et al. 2012, Piras et al. 2014) and for land-use or land cover changes (van Roosmalen et al., 2009, Ogden et al. 2011, 
Ogden and Stallard 2013, Ebel and Mirus 2014, Pierini et al. 2014, Niswonger et al. 2014).

They are also becoming increasingly critical in short-term forecasting of geomorphological hazards or inundation dynamics and in situations where complex feedbacks, such as landatmosphere coupling, are essential for accurate predictions. The renewed interest has been further boosted by the availability of computational resources and parallel computing approaches (e.g., Kollet et al. 2010, Vivoni et al. 2011, Gasper et al. 2014, Ogden et al., 2015a), as well as some degree of consensus in process representation (e.g., Maxwell et al. 2014).

In this article we review the value of distributed, process-based hydrological models to address a number of questions and highlight key challenges for future developments. We

100 discuss the importance of this fundamental approach in hydrology in the context of existing literature, avoiding descriptions of models and mathematical formulations, which have been recently reviewed (Paniconi and Putti, 2015). In the coming decades, hydrological research and water resources management will depend more heavily on our collective capacity to use models based on physical principles since these are essential instruments to formulate and test scientific hypotheses, investigate spatiotemporal patterns, improve our understanding of hydrological responses to a wide range of potential forcings and changes, and ultimately apply this improved understanding to better manage our finite water resources.

\section{Why process-based hydrological modeling?}

First, we provide a rigorous definition, to the extent possible, of the main subject of this contribution to lay the foundation for the subsequent discussion. Extending the line of

111 thought suggested by Brutsaert (2005), our definition links two notions: observability and

112 scale. Specifically, a process-based (or equivalently physically-based) hydrological model is

113 a mathematical formulation that explicitly represents and/or incorporates through assimilation 
114 approaches, the hydrologic state variables and fluxes that are theoretically observable and can

115 be used in the closure of assumed forms of the laws of conservation of mass, energy, and

116 momentum at temporal scales characterizing the underlying physical processes. When

117 applied spatially, from hillslope to continental scales, such a model can incorporate the space-

118 time variability of the primary forcings, such as precipitation and radiation, and variations of

119 land-surface properties (e.g., topography, soils, vegetation) at the sub-hillslope scale, while

120 resolving the subsurface domain in horizontal and vertical directions in a way to describe

121 heterogeneity at a scale equal to or larger than a representative elementary volume, for porous

122 media (see Bachmat and Bear, 1987, for a definition of representative elementary volume).

123 We further generalize the definition of a process-based model to a set of process

124 descriptions that are defined depending on the objectives at hand, be it rainfall-runoff 125 partitioning, vadose zone water fluxes, land-atmosphere exchanges, above and below-ground

126 non-isothermal dynamics, sediment or contaminant source identification, or a complete

127 description of hydrological dynamics. A growing number of these descriptions target one or

128 more processes including coupled subsurface and surface domains, land and atmospheric

129 processes, dynamic vegetation, biogeochemistry, and solute transport, and are applied at the

130 watershed and larger scales (e.g., Kuchment et al. 2000, VanderKwaak and Loague 2001,

131 Downer and Ogden 2004, Panday and Huyakorn 2004, Tague and Band 2004, Bertoldi et al.

132 2006, Kollet and Maxwell 2006, 2008a, Pomeroy et al. 2007, Qu and Duffy 2007, Li et al.

133 2008, Ivanov et al. 2008a, Markstrom et al. 2008, Rinehart et al. 2008, Sudicky et al 2008,

134 Ebel et al. 2008, 2009, Kumar et al. 2009, Drewry et al. 2010, Camporese et al. 2010, 2015,

135 Shen and Phanikumar 2010, Mirus et al. 2011a, Maxwell et al. 2011, Weill et al. 2011,

136 Vinogradov et al. 2011, Kolditz et al. 2012, Fatichi et al. 2012a,b, Kim et al. 2012a, 2013,

137 Shen et al. 2014, Endrizzi et al. 2014, Niu et al. 2014a, Shrestha et al. 2014, Xiang et al.

138 2014, Hwang et al. 2015, representing a non-exhaustive list). Although some of those 
139 process-based hydrological models include numerous distinct processes, the degree of

140 complexity and quantity of processes represented varies between models and influences the

141 suitability of a given model for specific applications.

142

143

144

145

146

147

148

\subsection{Parsimony is convenient but complexity is often necessary}

If simple explanations and parsimonious structures are able to highlight the emergence of general rules governing a system behavior, they are very often preferable to complex, high dimensional models. As suggested by Levin (1999) for ecological models: "...simple models are a good place to start because their transparent features provide clarity. A simple model is something to build on. In its sleek lines and limited assumptions, it can provide a base for elaboration while capturing the essence of a variety of more detailed possible explanations."

Simple models have been very useful and elegant in describing large-scale patterns that have features of self-similarity (scale invariance) that can be explained mathematically using fractal theory as well as exhibit the self-organization of complex adaptive systems, such as landscapes (e.g., Mandelbrot 1967, Rodriguez-Iturbe and Rinaldo 1997, Rinaldo 2009), ecosystems (e.g., Levin 1999) or flood quantiles (e.g., Smith, 1992, Goodrich et al. 1997, Ogden and Dawdy, 2003). For example, Muneepeerakul et al. (2008) was able to describe many features of fish biodiversity in the Mississippi-Missouri river network with a few parameters in a meta-community model. Other examples include the application of fundamental physical principles such as Maximum Entropy Production or Maximum Energy Dissipation to explain Earth system and hydrological processes (Kleidon et al. 2009, Wang and Bras 2009, 2010), as well as travel time approaches for reproducing coupled flow and transport processes (e.g., Benettin et al. 2013). These are examples where simplicity is useful and 'beautiful'. 

to understand how natural and human systems function and interact. Understanding the

167 general organization of a system does not provide information on how its principal 168 components interact nor does it elucidate the significance of its internal fluxes. The fact is 169 that topology, or where things are located and how they are connected within a watershed, 170 matters (Ogden et al. 2013). As a result, the complex and heterogeneous internal conditions 171 of a watershed escape description by lumped models, which are often difficult to apply to solve within-catchment problems because they rarely describe internal states and fluxes that are observable. In many cases, multiple processes and numerous complex feedbacks lead to 174 non-linear dynamics, instability, and tipping points (Pimm 1984) that can only be predicted 175 with a sufficient level of complexity with preservation of mass, energy, and momentum budgets. Examples come from studies of climate change effects, surface-subsurface interactions, and biogeochemical dynamics (e.g., Maxwell and Kollet 2008, Manning et al. 2009, Tague 2009, Drewry et al. 2010).

180 in specific variables at the local scale that can be simulated accurately only with detailed representations, such as sediment and contaminant transport (e.g., Ewen et al. 2000, Sudicky et al. 2008, Robles-Morua et al. 2012, Kim et al. 2013, Pradhan et al. 2014, Johnson et al. 2013, Niu and Phanikumar 2015), predicting land management impacts (Fatichi et al. 2014,

184 Pierini et al. 2014), landslide occurrence (Baum et al. 2008, Simoni et al. 2008, Shao et al. 185 2015, Anagnostopoulos et al 2015), snowpack evolution (e.g., Luce et al. 1998, Lehning et al. 2006, Endrizzi et al. 2014) or permafrost dynamics (e.g., Dall'Amico et al. 2011). Processbased models are also contributing to an improved understanding of different landatmosphere coupling regimes that are highly sensitive to the spatial heterogeneity of land 
190 2004, Maxwell and Kollet 2008, Santanello et al. 2011, Rihani et al. 2015, Bonetti et al.

191 2015, Davison et al. 2015). The use of well-constructed, process-based models should also

192 produce emerging patterns at large scales that build up from the small-scale complexity of a

193 watershed without tuning specific parameters, as supported by existing examples (e.g., Kollet

194 and Maxwell 2008b, Vivoni et al. 2010, Kim et al. 2012b).

195 There is a widespread perception that multi-disciplinary process-based models with a

196 high-dimensional parameter space produce results that can span an unreasonably large range

197 of states (e.g., McDonnell et al. 2007). Therefore, the use of these models is often regarded as

198 introducing several layers of uncertainty, including numerous, generally poorly known,

199 parameter values describing different processes. Despite the large dimension of the parameter

200 space, process-based models are less reliant on calibration or tuning because parameter

values can be constrained directly by the physical relations or observable quantities (Figure

202

1). While this is not true for all parameters, many of them can be estimated with a given

uncertainty from observations or expert considerations (e.g., Hubbard and Rubin 2000,

204 Kowalsky et al. 2004, Gleeson et al. 2011, Gupta and Nearing, 2014, Bahremand 2015),

205 therefore constraining a priori the range of model responses; some claim excessively

206 (Mendoza et al. 2015). Spatial patterns of the inputs imposed by distributed datasets further

207 constrain the basin-internal dynamics. Additionally, the number of sensitive parameters in spatially-distributed process-based models, per process accounted for, is often similar to

209 simpler models (Pappas et al. 2013). Accounting for spatial heterogeneity can complicate

210 parameter identification but surrogate information, such as soil type, land-use, and geology

211 data, can be used to group similar regions into areas with similar parameter values (e.g.,

212 Samaniego et al. 2010).

213 Additional processes and components recently coupled to hydrological models (e.g.,

214 vegetation dynamics, soil biogeochemistry, sediment transport, solute and water-age, 
atmospheric boundary layer, snow and soil thermal regime) not only increase the parameter space, but also the number of constraints on the system response. These constraints emerge

217 from the model internal structure and dependencies, and the larger number of states and

218 fluxes that can be compared to observations at commensurate scales, rather than from a

219 formal model calibration. These additional simulated processes can involve observable variables and aid in constraining parameter values. For instance, correct simulations of leaf area index seasonal dynamics and stomatal aperture in an ecohydrological model are likely to result in an adequate simulation of canopy radiation exchanges and transpiration fluxes.

223

\subsection{The need for virtual experimentation laboratories}

Physics, meteorology, and geomorphology are all examples of fields where the use of model experiments or the definition of theories precedes the validation and test of the theory through observations. For example, the existence of black holes (Schwarzschild 1916, Kerr 1963) and cosmic microwave background (Gamow 1948) were theorized well before the actual observations were made. Other disciplines, for instance structural engineering, soil science and plant physiology, have relied to a larger extent on physical experiments and observations. Consequently, theories have typically followed experiments, though striking exceptions exist, such as the cohesion-tension theory for plant vascular transport (Tyree 1997, 2003). The field of hydrology has evolved with elements of these two categories. Field experiments in hydrology are difficult and expensive due to the relevant spatial scales, instrumentation requirements for measuring a wide variety of variables, especially in the subsurface, and the spatial heterogeneity of hydrological states and fluxes. Nonetheless, both intense field campaigns and long-term experimental watersheds have been conducted at various levels of comprehensiveness (e.g., Swank and Crossley 1988, Hornbeck et al. 1993, Blackmarr, 1995, Western and Grayson 1998, Jones 2000, Slaughter et al. 2001, Tromp-van 
241 Meerveld et al. 2008, Ogden et al. 2013). Concurrently, since long-term precipitation and 242 streamflow observations are available globally and have been a hallmark of hydrologic 243 science, our community has also developed many models with the objective to match these 244 sparse observations (see discussion in Loague and VanderKwaak 2004). As a result, 245 hydrologic science has devoted a minor effort to virtual experiments that can be used to 246 develop theories or propose hypotheses that can subsequently be tested in the field. Yet process-based models can effectively serve as virtual laboratories to quantitatively address questions related to spatial patterns and temporal dynamics of coupled processes. With virtual experiments we refer to numerical simulations carried out to test a scientific hypothesis, which will be difficult or impossible to investigate otherwise. These are different from studies aimed at comparing models among themselves or validating model results. Early efforts were focused on identifying knowledge gaps, such as how soil unsaturated hydraulic properties and snow melt control runoff (Stephenson and Freeze 1974). More recently, virtual experiments have become widely used for hypothesis testing on hillslope-scale processes such as macropore flow (Weiler and McDonnell 2004), surfacesubsurface interactions (Park et al. 2011), lateral connectivity (Mahmood and Vivoni 2011), nonlinear storage-discharge dynamics (Camporese et al., 2014b), and throughfall (Frasson and Krajewski 2013). Similarly, the advent of coupled-process models has allowed more sophisticated hypothesis development and testing of runoff generation across the 260 surface/subsurface interface (Niedzialek and Ogden, 2004, Ebel et al. 2007a,b, Loague et al. 261 2010), channel-land interactions (Shen et al. 2016), and non-uniqueness of soil moisture distribution (Ivanov et al. 2010, Fatichi et al. 2015a) and soil erosion and sediment transport 263 (Kim and Ivanov 2014). This approach further facilitates extrapolation from individual catchments to generalizations across different environmental conditions (Mirus and Loague 2013). For example, ecohydrological process models have allowed virtual experiments 
related to vegetation dynamics across a range of scales (Ivanov et al. 2008b, Shen et al. 2013,

Della Chiesa et al. 2014, Fatichi et al. 2014, 2015, Pierini et al. 2014, Mendez-Barroso et al.

2014). Perhaps the most useful type of virtual experiments for advancing hydrological understanding will be applications that closely match real systems. In fact, process-based models allow an extension of investigations to temporal and spatial domains and resolutions that are beyond the capabilities of traditional field studies (e.g., Mirus et al. 2011b, Fatichi et al. 2014, Mascaro et al. 2015).

Some studies have already shown the utility of models for the design of experimental hillslopes or catchments with sophisticated monitoring networks, such as Biosphere 2 (Hopp et al. 2009, Ivanov et al. 2010, Niu et al. 2014b). Along these same lines, the development of virtual and physical laboratories such as the Chicken Creek experiment (Holländer et al. 2009) can provide data for unbiased testing of model parameterizations. The continued expansion of coordinated monitoring networks, such as the Critical Zone Observatories (CZOs) (Anderson et al. 2008) and TERENO (Zacharias et al. 2011, Grathwohl et al. 2013), will ultimately rely on numerical modeling to provide generalization to other regions and insights on questions about the value of observations and the limits of our current process understanding.

Finally, high-resolution modeling at large scales (e.g., Wood et al. 2011, Bierkens et al. 2015, Maxwell et al. 2015) can facilitate virtual experiments to address questions that would not be feasible with the current generation of satellite and ground-based measurements alone. This integration will possibly produce a shift from data-driven studies that inform numerical modeling to the use of model-driven hypothesis testing to inform data acquisition. 
Using the conventional "top-down" and "bottom-up" terminology to describe

291 different approaches (e.g., Sivapalan et al. 2003), process-based modeling approach falls

292 naturally into the latter category. That is, a distributed process-based model relies on multiple

293 components that are combined together to contribute to the overall dynamics at a higher

294 organizational level, such as a watershed. The complexity thus results from interactions of user-selected fundamental process formulations operating at fine spatial and temporal scales.

In contrast, "top-down" models rely on constitutive relations or parameterizations to describe

finer-scale behavior from the coarse model scale. Often, this is done with a limited attempt to resolve observable mechanisms, distributed patterns, and feedbacks operating at small-scale

299 levels. Of course, one possible fallacy of the "bottom-up" approach is the inclusion of elements or hierarchical levels in the model that contribute little towards the overall system behavior or overly emphasize dependencies because of lack of process understanding; for instance, interactions between processes that lead to excessive dampening or intensification of the system response relative to actual behavior. process descriptions often rely to some extent on first principles for rigor. In theory, at the appropriate scale, these process-level components are verifiable approximations of reality with no, or limited, recourse to empiricism. As such, formulations are independent of 308 immediate data availability, but highly amenable to testing with new observations in a

309 validation procedure. Data sets for testing process-based models may be of heterogeneous 310 types at individual locations or distributed in nature, for example as continuous time series 311 (e.g., soil moisture, energy fluxes, stream flow), instantaneous records (e.g., satellite derived 312 evapotranspiration, biomass, snow water equivalent, tracer concentrations, suspended 313 sediment concentration), or qualitative observations (e.g., presence or absence of snow or 
inundation), among others. With the increase in the number and quality of remote sensing platforms, the ability to use such observations of internal states and fluxes will rise in importance (e.g., Niu et al. 2014c, Xiang et al. 2014, Mascaro et al 2015, Figure 2).

Finally, the interactions of individual elementary responses represented in processbased models lead to emergent patterns in space and time that are unlikely to be identified using coarse-resolution approaches. For example, discoveries of new mechanisms and feedbacks depending on spatial interactions have already been documented using processbased models (e.g., Maxwell and Kollet 2008, Ivanov et al. 2008b, Vivoni et al. 2010, Rihani et al. 2010, Le et al. 2011, Mahmood and Vivoni 2011, Hwang et al. 2012, Kim and Ivanov 2014, Bearup et al. 2014, Rahman et al. 2014).

\subsection{Non-stationarity: we live in a transient age}

Human impacts at the watershed scale have increased since industrialization.

Environmental changes, such as those associated with the construction of hydraulic infrastructure, changes in land-use or transient climate alter the amount and distribution of water resources (e.g., Gleeson et al., 2012). An emerging realization is that climate change has likely pushed the hydrologic cycle out of what is considered statistical stationarity (Held and Soden 2006, Milly et al. 2008, 2015, Melillo et al. 2014). A non-stationary future calls for tools that are reliable and sufficiently general, can permit robust assessments and planning, and also operate at the scales of "human action", that is, at space and time

334 resolutions that are immediately relevant for the purposes of design, planning, and management.

In a spatial context, a process-based model can reflect variations at sub-hillslope and stream reach scales, as well as integrate variations of landscape characteristics that control hydrological connectivity in surface and subsurface flow paths. This is close to the localized, 
339 "human action" scales (e.g., Piras et al. 2014, Fatichi et al. 2015b, Kim and Ivanov 2015).

340 Process-based models are natural candidates for assessments of non-stationary systems

341 because mass, energy, and momentum fluxes are conserved, and model skills are informed by

342 state variables and fluxes that can theoretically be measured directly. Process-based models

343 also offer a convenient means for addressing the related uncertainty by combining stochastic

344 and deterministic modes of operation (Kuchment and Gelfan 1991). Furthermore, the 345 parameter or forcing variations imposed to the model to address non-stationary conditions

346 can be established either objectively, using a well-defined scenario, or subjectively through

347 the application of sensitivity (stress) analyses (e.g., Mascaro et al. 2010, Steinschneider et al.

348 2014, Kim and Ivanov 2015).

\subsection{The underpinning of environmental sciences: interdisciplinarity}

The problems addressed by hydrological models are interdisciplinary in nature by virtue of the cross-thematic properties of water as a solvent, erosive agent, disease vector, exchange medium for energy, recreational element, human, animal and plant consumable, and, ultimately, an economic quantity. For this reason, interdisciplinarity is at the heart of hydrologic science (Eagleson 1991). Hydrological processes are inherently multi-scale in that the dominant controls on fluxes and residence times within various disciplines are expressed differently across a wide range of spatial and temporal scales. Given the nature of many interdisciplinary problems, process-based models that solve explicitly observable states and

359 fluxes at high spatial and temporal resolution and possess appropriate multi-scale 360 representation capabilities are the most likely candidates for interdisciplinary research.

361 For example, the number of studies that combine process-based hydrological models

362 designed for unsaturated and saturated subsurface flow with models that solve land-surface 363 energy exchanges and/or ecological dynamics are increasing (e.g., Rigon et al. 2006, 
364 Maxwell and Kollet 2008, Ivanov et al. 2008a, Siqueira et al. 2009, Maxwell et al. 2011, 365 Banks et al. 2011, Vivoni 2012b, Moffett et al. 2012, Fatichi et al 2012b, Condon et al. 2013, 366 Shen et al. 2013, Ng et al. 2014, Niu et al. 2014a, Endrizzi et al. 2014). However, the 367 integration of process-based hydrologic models within a single modeling framework of the

368 Earth's system that encompasses multiple disciplines is still largely unrealized (e.g., Paola et 369 al. 2006, Flato 2011) and descriptions of hydrology in current Earth systems models do not 370 yet reflect a suitable level of hydrologic process understanding and modeling solutions (Clark et al. 2015).

For hydrologists trained in geology, engineering or geography, making the substantial

373 leap to interdisciplinary research with geomorphologists, atmospheric scientists, ecologists or

374 biogeochemists might not be too difficult. However, human-oriented disciplines such as socio-economics, policy, and law are also essential for taking hydrological modeling expertise and products into stakeholder engagement activities and the valuation of hydrological services to society (Srinivasan et al. 2012, Guswa et al. 2014, Niswonger et al. 2014). Current trends in science and engineering point to greater integration of disciplines and hydrological modeling is considered to be a building block that determines which transdisciplinary, multi-sectorial and multi-objective scenario-based simulations, and output interpretation can be performed. This perception is due in large part to the emphasis that the hydrological modelers have placed on process-based understanding and in building predictive systems that capture the impact of changes in measureable quantities on hydrological parameters and subsequent effects on the fluxes of water and its constituents. Boundaries of hydrologic science will continue to expand and hydrologists will be integral components of new and emerging fields, which can benefit from the quantitative and computational skills emphasized in process-based hydrological modeling. Much is also to be learned from allied disciplines, where the lack of process-based computational tools has fine- 
tuned the ability of investigators to pose testable hypotheses through limited field experimentation or the ability to interpret cause-effect relationships on theoretical arguments

391 rather than simulation-based results. Given the likely increase in reliance upon process-based 392 hydrological modeling in multi-disciplinary studies, the responsibility lies with our 393 hydrological community to develop tools that are broadly and conveniently applicable, while 394 continuing to use these tools for hypothesis-driven research. Furthermore, providing nonspecialists use of process-based algorithms will help to minimize what Klemes (1986) criticized as "dilettantism in hydrology".

\section{Practical issues}

Despite the arguments in favor of process-based hydrological models reviewed here, some still resist the use of these models. This is largely due to practical matters. Conceptual models are much easier to use at coarser scales and require a lower threshold of process knowledge and expert training, making them more widely appealing. This occurs at the expense of a considerable time investment in model calibration and possibly a reduced model performance, when used outside of the calibrated range of conditions (Uhlenbrook et al. 1999, Seibert 2003). As a result, a wider dissemination of process-based approaches will require improved model visualization tools, a streamlined approach for model setup, execution and output analysis, and improved communication of the model capabilities and limitations to potential adopters. This is required to avoid the problem of "garbage in, garbage out", where unprepared users operate complex models in an inappropriate fashion obtaining untrustworthy results. Intuitively, direct simulation of coupled processes is more straightforward to understand than a conceptual representation of system response. In reality,

411 the implementation of coupled processes typically requires complex numerical methods with 412 associated risks regarding numerical instability and convergence, whereas conceptual 
413 representations are less prone to these problems. Furthermore, consistent applications of

414 process-based models require that the user understands the underlying processes and their

415 interactions as well as the mathematical and computational representation. This requires a 416 deeper understanding of hydrology and numerical techniques, which can be seen as an

417 opportunity to improve the training of students and practitioners in hydrologic sciences.

418 Hydrological models with the most complete descriptions of processes require data 419 rich settings (e.g., Camporese et al. 2014a,b, Mascaro et al. 2015). However, models that 420 require large amounts of data are unlikely to find widespread use because of data limitations 421 and user limitations to process data. Wider use of these models must hinge on a more 422 systematic approach for mining existing data repositories from governmental and/or 423 commercial sectors. In the United States, for instance, spatial data needed to drive process424 based models are now freely available from a variety of sources, such as the U. S. Geological 425 Survey (USGS) seamless data viewer (http://nationalmap.gov/viewer.html) and the National 426 Resources Conservation Service (NRCS) web soil survey 427 (http://websoilsurvey.sc.egov.usda.gov/App/HomePage.htm). Precipitation data from 428 multiple platforms are available from the National Center for Environmental Information 429 (NCEI, formerly known as National Climatic Data Center, http://www.ncdc.noaa.gov/). It is 430 possible to obtain additional meteorological forcings from the North America Land Data 431 Assimilation System (NLDAS) (http://www.emc.ncep.noaa.gov/mmb/nldas/). Datasets to 432 characterize river hydraulic morphology (e.g., Allen and Pavelsky, 2015) and global 433 hydrogeological maps (Gleeson et al. 2014) are also becoming available. Process-based 434 models that can be driven by readily available geospatial data sources from standard web435 based interfaces are likely to be applied more widely by diverse users (e.g., Kumar et al. 436 2010, Gochis et al. 2014, Bhatt et al. 2014, Formetta et al. 2014). 

equations with the aim of solving large domains at fine temporal and spatial resolutions, the model computational burden is a serious issue. Simulation times increase as more processes are included, as process descriptions become more general, and as spatial and temporal resolutions are increased. Even in the case where a single simulation does not require a long time, there are practical issues related to stochastic approaches that might require hundreds or thousands of simulations (e.g., Skahill et al. 2009, Camporese et al. 2009a, Pasetto et al. 2012, Moreno et al. 2013). Since different physical processes (e.g., transpiration, infiltration, snow metamorphism, groundwater flows) have different dominant time scales ranging from a few minutes to many years, approaches using sub-time stepping can be regarded as a way of improving the computational performance (e.g., Park et al. 2008, 2009). However, the tradeoffs between process representation and physical realism remain unevaluated, and different process-based models have various degrees of complexity.

A classic example is represented by numerical solutions of the Richards equation, which are used by process-based models to solve water fluxes in variably saturated porous media. The use of the Richards equation to solve soil-water flow dynamics in process-based models has been criticized for over-emphasizing capillarity and neglecting the role of preferential flow (Nimmo, 2012, Beven and Germann 2013), for being in some ways 'overly simplistic' (Gray and Hassanizadeh, 1991, Niessner and Hassanizadeh 2008), and for being computationally expensive and sometimes unstable and unreliable (e.g., Tocci et al. 1997). The last point posed limitations to large-scale fine resolution applications of process-based models. However, process-based formulations that deal with preferential flows have been introduced (e.g., Gerke and van Genuchten, 1993, Šimůnek et al. 2003) and numerical methods for solving 2D and 3D Richards equation in an accurate and reliable way have been developed 461 (e.g., Paniconi and Putti, 1994, Neuweiler and Cirpka 2005, Mendicino et al. 2006, An et al. 
2010, Lott et al. 2012), as well as methods to derive effective soil hydraulic parameters as a

463

464

465

466

467

468

469

470

471

472

473

474

475

476

477

478

479

480

481

482

483

484

485

function of hillslope topography (e.g., Jana and Mohanty 2012). Recently, an alternative general one-dimensional solution of the vadose zone flow problem has been also presented (Talbot and Ogden 2008, Ogden et al. 2015b,c, Lai et al. 2015) and can considerably reduce computational times in comparison to classic solutions of the Richards equation.

More generally, code parallelization is an essential requirement to reduce computational times for large problems (Kollet et al. 2010, Vivoni et al. 2011, Eller et al. 2013, Ran et al. 2013, Hwang et al. 2014, Ogden et al. 2015a). The Message Passing Interface (MPI) and Open MP set of tools, which provide open-source libraries for developing parallel computing capabilities within model codes, can reduce simulation times significantly on multi-processor desktop machines. One alternative for massively parallel computations is the use of General Purpose - Graphical Processing Units (GP-GPUs) based on the GPUs originally developed to improve graphics rendering of computer animations, with initial applications underway in hydrological and hydraulic modeling (e.g., Kalyanapu et al. 2011, Hughes and White 2013, Anagnostopoulos et al. 2015, Le et al., 2015, Lacasta et al, 2015, Falter et al., 2015).

\section{Avenues for future advances}

\subsection{Toward fully integrated natural and virtual laboratories}

A key challenge facing hydrological modeling is the integrated use of natural and virtual laboratories to advance theory and process understanding, and develop and test new approaches. Too often, the model development occurs in isolation from field experimental activities or within specific geographic regions where the model is desired. While model generality is an admirable goal, it should not justify disconnecting modeling activities from field knowledge. Natural laboratories or physical models of natural systems (laboratoryscaled versions of plots or hillslopes) are likely to become an indispensable part of a 
hydrological modelers' toolkit. At experimental sites, instrumentation networks and field sampling allow coordinated, simultaneous measures of the states and fluxes of the hydrologic, atmospheric, geomorphic, ecologic or biogeochemical processes of interest. Along with knowledge of system characteristics, natural laboratories provide essential datasets to test the ability of models to capture the system behavior under different forcing or initial conditions, thus challenging the accuracy and fidelity of individual processes and the emergent behavior at specific locations and averaged over a spatial domain. Fortunately, prior calls to reduce the disconnection between experimentation and modeling and to reconcile soft and hard hydrological data (e.g., Seibert and McDonnell 2002) have led to substantive progress. A growing number of hydrological modelers are participating in multi-disciplinary experimental sites, such as the Critical Zone Observatories, Landscape Evolution Observatory and Long-Term Ecological Research sites (e.g., Hobbie et al. 2003, Anderson et al. 2008, Huxman et al. 2009), where modeling and observation activities are coordinated. A number of small-scale (100s of $\left.\mathrm{m}^{2}\right)$ artificial catchments and experimental sites, where boundary conditions can be carefully controlled (Kendall et al. 2001, Nicolau 2002, Gerwin et al. 2009), are also available for this purpose. However, few of these sites, with some exceptions (Hopp et al. 2009, Vivoni 2012a), have used hydrological modeling for formulation or testing of hypotheses, presenting an opportunity to expand the utility of process-based modeling tools. In addition to natural observatories, a new generation of distributed hydro-geophysical measurements (e.g., light detection and ranging, ground penetrating radar, distributed fiber optic temperature sensors, electrical resistivity tomography, phenological cameras, large aperture scintillometers) and remote sensing products from satellite and aerial platforms, including unmanned aerial vehicles, are also being used to improve the characterization of 
511 (e.g., Robinson et al. 2008, Steele-Dunne et al. 2010, Panciera et al. 2014, Vivoni et al. 2014,

512 Singha et al. 2014). Measurements aimed at improved process-level understanding naturally

513 aid in the simulation of those processes. Long-term investments for collection of datasets

514 specifically designed for testing process-based hydrological models would pay substantial

515 dividends to model development and to the closer integration of natural and virtual

516 laboratories.

517 In many cases, the breadth and depth of the data generated from natural observatories

518 and remote sensing is astounding, raising significant questions on how to properly use them

519 in hydrological modeling development and testing. The current widespread field-scale data

520 collection in natural laboratories and proliferation of data-sharing requirements by funding

521 agencies and journals should be helpful to hydrological modelers in multiple ways - helping

522 in the design of sensor networks, aiding in the appropriate level of spatiotemporal

523 aggregation of data for use in models, and providing model-based insights into the key

524 variables to measure for advancing theory and process-level understanding. Process-based

525 distributed modeling can in fact benefit from improved model-data fusion (e.g., Vrugt et al.

526 2005, Hyndman et al. 2007, Camporese et al. 2009a,b, Hinnell et al. 2010, Kerkez et al. 2012,

527 Mascaro and Vivoni 2012, Pasetto et al. 2012, Vrugt et al. 2013, Mirus 2015). Furthermore,

528 improved assimilation of data with different origins (i.e., in situ, remote sensing, Lagrangian

529 sampling, point-, 2D and 3-D scales) will speed model testing and process-level validation.

530

531

532

4.2 From watershed scales to stakeholder scales

Hydrological models have traditionally focused on watershed-scale quantities such as streamflow or integrated water budgets. However, localized scales - a stream reach, a

534 floodplain, an agricultural field, or a stormwater sewer - provide societal relevance and 535 interest in the impacts of land-use or climate changes that are typically much stronger when 
536 predictions concern local, "backyard", problems such as urban flooding, water quality and 537 aquatic habitats, or morphological variations in a channel or landscape. Addressing problems 538 at these scales very often require interdisciplinary models based on physical processes. What 539 is more, these scales are in some ways ideal for process-based approaches. For instance, the 540 computation of metrics, such as shear stress and turbulent kinetic energy, are pivotal for 541 investigating streamflow effects on the aquatic environments for fishes (Crowder and Diplas 542 2002, 2006). In practice, this can only be achieved by coupling process-based hydrological, 543 hydrodynamics and sediment transport models (e.g., Heppner et al. 2007, Kim et al. 2012a,b, 544 2013, Kim and Ivanov 2015). Furthermore, the hydrological modelers should continue to demonstrate that state-of-

546 the-art hydrological predictions are useful to society. Demonstration of this worth is a 547 laudable objective. This might seem obvious to hydrologists as our education, practical 548 training, and research experiences have largely been motivated by the desire to improve the 549 public good through, for example, enhanced warning systems, more resilient and robust 550 infrastructure or better water resources management plans. However, in the process of 551 building, testing and deploying modeling systems, there is a real risk of creating a disconnection from stakeholders who, ultimately, will benefit from or be impacted by the hydrological predictions. This can be attributed to the difficulty in communicating complex ideas or modeling structures, but also to the lack of training and expertise currently in our 555 field in the realm of stakeholder engagement activities (e.g., Hatzilacou et al. 2007, White et al. 2010). It is noteworthy that the keystone of hydrological modeling in engineering and regulatory practice remains today the curve number approach, despite all its empiricism and established shortcomings (e.g., Garen and Moore 2005). task. Conveying the nuances and difficulties associated with modeling assumptions, spatial 
and temporal resolutions, parameter estimation, or coupled model components to nontechnical audiences is even more difficult. Despite this, we believe that an effort to disseminate the capabilities of process-based modeling to non-technical decision makers is crucial, because of its central role in quantifying the complex interplay between hydrological processes and human decisions (e.g., Srinivasan et al. 2012, Sivapalan et al. 2012, 2014). In this context, the requirements of hydrological models are far greater when a system description includes humans and their interventions. For example, it is not uncommon that the biophysical and geochemical processes represented in hydrological models would need to interact with active agents who make individual or group decisions that affect these coupled processes in nonlinear ways (e.g., time-varying water extractions or diversions, pollution sources, land cover changes) (e.g., Parker et al. 2003, Bomblies et al. 2008). Building realism into the simulation of these complex interactions necessitates the use of process-based hydrological models that can be coupled to models that represent these decision dynamics at a compatible scale.

\subsection{Short-term predictability of hazards and engineering design}

One of the most common and perhaps justified criticisms of process-based models is that they produce limited improvement over calibrated operational models for short-term streamflow predictions. This is due to the large uncertainty in the knowledge of boundary and initial conditions, as well as the difficulty of a formal calibration of the large parameter space (e.g., Senarath et al. 2000). However, the ability of calibrated models to mimic short-term hydrological responses also leads to over-confidence in their predictive skills. Calibration procedures that do not account for uncertainty in input and output observations and model structure inevitably lead to biased parameter values (e.g. Restrepo and Bras 1985, Ajami et al. 2007, Renard et al 2010). We argue that process-based models are equally useful tools for 
short-term predictions of natural hazards and for engineering design; additionally, they are less subject to biased parameters arising from intensive calibration exercises. Short-term predictions using process-based models typically involve minor computational efforts, therefore stochastic simulations that account for uncertainty ranges of parameter values, 590 forcings and initial conditions are feasible.

In fact, process-based models are increasingly used to provide alerts and mitigation measures for short-term hazards, such as floods, avalanches and landslides. For instance, the U.S. National Weather Service (NWS) is now implementing a process-based hydrological model as its centralized national modeling system (Gochis et al. 2015). While NWS will also still run lumped conceptual models, the fact that it is embarking on this new direction is a confirmation of the idea that process-based models could improve complete hydrologic cycle forecasting. The clearest advantage of process-based models is their ability to bring critical information about state variables, such as flow depth, into the simulation through the use of data assimilation of non-conventional variables and/or properly formulated dynamic

600 boundary conditions (Figure 3). A classic case is coastal flooding due to tides and storm 601 surge (Lin et al. 2012). For certain episodic flooding events, such as Hurricanes Irene and 602 Sandy that affected the northeast U.S. coast, these effects are the dominant flooding process. In these events, encouraging examples come from the U.S. Army Corps of Engineers, which 604 provided, with the process-based hydrological model GSSHA (Downer and Ogden 2004), 605 predictions of flooding extent and depth that were used to plan evacuations (Massey et al. 606 2013). Another example is potential for real-time prediction of landslide hazards, including 607 the proof of concept system built upon the model GEOtop (Rigon et al. 2006, Endrizzi et al. 608 2014) or the exploration of rapid operational application of TRIGRS (Raia et al. 2014). 
611 pollution control). While the effect of individual controls is mostly localized, the system of

612 different structural controls influences the entire watershed or river reach of interest. Within a

613 conceptual modeling framework, the effect of controls can only be approximated by an $a$

614 priori estimation of the effect of individual structures, thus the entire system effect is the

615 estimated sum of the individual parts without accounting for locations and feedbacks between

616 various controls. On the other hand, a process-based approach can explicitly simulate features

617 at the approximate locations, sizes and with varying functions. For instance, urban flood

618 control measures may include surface retention, subsurface drainage, levees, pumping and

619 water diversions. Unexpected feedbacks between these controls can render them inadequate,

620 useless, or even detrimental. Process-based models capture boundary effects, flow paths, and

621 effects of topology and thus solve for the total system response, facilitating the design and

622 collocation of critical components. For example, the use of the process-based GSSHA model

623 (Downer and Ogden, 2004) in designing a flood control system in Florida by the U.S. Army

624 Corps of Engineers led to a documented savings of over $\$ 40$ million over standard practice

625 using separate hydrology and hydraulics models (Downer et al. 2015).

626

627

628

630

631

632

633

634

635

636

\subsection{Introducing the stochastic component}

There is no doubt that the current use of process-based models is mostly deterministic, with few examples merging theoretical frameworks (Kuchment and Gelfan 1991, Kuchment et al. 1996) and ensemble approaches to date (e.g., Forman et al. 2008, Mascaro et al. 2010, Kim and Ivanov 2015). This is likely a result of the large computational requirements of process-based distributed simulations rather than an underestimation of the involved uncertainties. While the deterministic nature of current process-based models is a limitation, it also leaves room for improvements using stochastic approaches. An exact and detailed knowledge of all the system properties (e.g., bedrock topography, soil-hydraulic properties, vegetation physiology) will likely remain elusive in the foreseeable future. As a result, 
uncertainty will unavoidably persist in several parameters as well as in the model structure. It immediately follows that uncertainty must be treated using an appropriate framework (e.g., Montanari and Koutsoyiannis 2012). Many approaches and methodological tools have been

640 presented to deal with uncertainty in hydrological modeling (e.g., Beven 2006, 2008,

641 Montanari 2007, Koutsoyiannis 2010). However, applications of these approaches have been

642 mostly carried out using coarse, conceptual models applied to watersheds (Beven and Freer 643 2001, Montanari 2005, Vrugt et al. 2005) or groundwater hydrology models (e.g., Hill and

644 Tiedeman 2007). Making these varying approaches suitable for use with process-based 645 models coupling surface and subsurface domains requires an easing of the large 646 computational burden of numerical stochastic techniques (e.g., Pasetto et al. 2013).

647 More importantly, we need a systematic approach to rank the sources of uncertainty 648 and address primarily those implying larger effects on the results of interest. Regardless of 649 the computational issues, many theoretical problems still remain to be tackled, such as how to 650 deal with system non-stationarity, the definition of likelihood distributions for inputs and 651 model parameters, and the cross-correlations among the various sources of uncertainty. While 652 computational and theoretical problems can currently represent a daunting challenge, treating uncertainty through a synthesis of process-based models and stochastic approaches may represent a fundamental leap forward in the field of hydrologic science. The recent progresses in surrogate modeling or meta-modeling (Razavi et al. 2012a,b, Castelletti et al. 2012, Wang et al. 2014) or specific downscaling techniques to increase output resolution 657 (Pau et al. 2016) suggest that the use of process-based models in settings that require thousands of model evaluations may be feasible. These advances may alleviate the issues of prohibitive computational cost in optimization or uncertainty quantification contexts. 
662 exist. We describe a series of opportunities and modeling challenges where a high spatial and/or temporal resolution and a refined representation of hydrological processes are required

664 by the complexity of the real world and by the fact that flow path and heterogeneity of land surface properties are important. Distributed estimates of soil moisture, evapotranspiration, sediment and pollutant transport are examples where explicit modeling of flow paths and 667 residence times are warranted because they have a dominant effect on the solution. Interdisciplinary studies of ecohydrology, carbon cycle, riparian processes, flood and landslide hazard predictions, cold season processes, and land-atmosphere interactions benefit from process-based hydrological models because conservation of mass, energy and momentum is often a pre-requisite for these problems. They also fall in the class of question

672 that require explicit representation of spatial patterns and temporal dynamics of fluxes and state variables (e.g., soil moisture and temperature, snow water equivalent, runoff generation, etc.). Better understanding and simulation of human disturbances of hydrological systems, for instance climate and land use changes, are also strong incentives to implement process-based solutions. We review reasons why the integration of small-scale complexity is likely to

677 succeed in establishing causal relations between processes, parameters, and outcomes in reproducing emergent responses and patterns at larger scales. Using process-based models based only on a priori information could be foreseeable in the near future, but this strongly hinges on the capability of using large amount of information currently available in constructing, testing, and setting-up the models, and appropriately accounting for the related 682 uncertainty through stochastic approaches. Practical issues connected with process-based models, such as difficulty in their use, scalability of physical laws, prohibitive computational times and a large number of parameters, have hampered widespread adoption of these tools. 
685 Arguably, detailed characterizations of hydraulic properties of the subsurface and flow paths 686 still represent the most significant obstacle for widespread use of process-based hydrological

687 models. This should challenge the hydrologic science community to develop innovative ways 688 to measure these key variables. Recent developments in parallel computing resources, new 689 ground-based or remote sensing tools and data collection methods, and new data sources 690 (e.g., tracers and geophysical techniques), will hopefully help resolve some of these barriers 691 and facilitate a more comprehensive treatment of uncertainty. Better integration between 692 virtual and natural laboratories can additionally help in developing model validation datasets 693 and further refining the representation of specific processes. There are ample opportunities 694 for leveraging the utility of process-based models beyond what has been achieved so far and 695 we encourage hydrologists to seize this opportunity.

696

697 Hydrologic Modeling: Challenges and Avenues for Development" at the American 700 Geophysical Union Fall Meeting 2013 in San Francisco, USA. Luke McGuire, USGS, provided a useful review of an earlier draft of this manuscript. We thank Massimo Dotti for the references about astrophysics. SF thanks the support of the Stavros Niarchos Foundation and the ETH Zurich Foundation (Grant ETH-29 14-2). VI acknowledges the support of NSF Grant EAR 1151443. MS acknowledges financial support from SFB/TR32 (Patterns in Soil-

705 Vegetation-Atmosphere Systems: Monitoring, Modeling, and Data Assimilation) funded by 706 the Deutsche Forschungsgemeinschaft (DFG). Any use of trade, firm, or product names is for descriptive purposes only and does not imply endorsement by the U.S. Government. 


\section{References}

Abbott, M. B., J. C. Bathurst, J. A. Cunge, P. E. O'Connell, and J. Rasmussen (1986). An introduction to the European hydrologic system-systeme hydrologique Europeen, SHE, 1: History and philosophy of a physically-based, distributed modeling system. J. Hydrol., 87, 45-59.

Ajami, N. K., Q. Duan, and S. Sorooshian (2007), An integrated hydrologic Bayesian multimodel combination framework: Confronting input, parameter, and model structural uncertainty in hydrologic prediction, Water Resour. Res., 43, W01403, doi:10.1029/2005WR004745.

Allen, G. H. and T. M. Pavelsky (2015). Patterns of river width and surface area revealed by the satellite-derived North American River Width data set. Geophys. Res. Lett. 42, 395402. doi:10.1002/2014GL062764

An, H., Y. Ichikawa, Y. Tachikawa, and M. Shiiba, (2010). Three-dimensional finite difference saturated-unsaturated flow modeling with nonorthogonal grids using a coordinate transformation method. Water Resour. Res., 46, W11521 doi:10.1029/2009WR009024

Anagnostopoulos G. G., S. Fatichi and P. Burlando (2015). An advanced process-based distributed model for the investigation of rainfall-induced landslides: The effect of process representation and boundary conditions. Water Resour. Res., 51, doi:10.1002/2015WR016909

Anderson S. P., R. C. Bales, and C. J. Duffy (2008). Critical Zone Observatories: Building a network to advance interdisciplinary study of Earth surface processes. Mineral. Mag., 72, 7-10.

Bachmat, Y. and J. Bear (1987). On the concept and size of a representative elementary volume (REV). Advances in transport phenomena in porous media, Martinus Nijhoff, Dordrecht, The Netherlands, 5-20.

Bahremand, A., (2015). Advocating process modeling and de-emphasizing parameter estimation. Hydrol. Earth Syst. Sci. Discuss., 12, 12377-12393, doi:10.5194/hessd-12$12377-2015$

Banks, E. W., Brunner, P., and Simmons, C. T. (2011). Vegetation controls on variably saturated processes between surface water and groundwater and their impact on the state of connection. Water Resour. Res., 47, W11517, doi:10.1029/2011WR010544. 
Baum R. L., Godt J.W., and Savage W. Z. (2008). TRIGRS - a Fortran program for transient rainfall infiltration and grid-based regional slope-stability analysis, version 2.0: U.S. Geological Survey Open-File Report, 2008-1159, pp 75

Bearup, L. A., R. M. Maxwell, D. W. Clow, and J. E. McCray (2014). Hydrological effects of forest transpiration loss in bark beetle-impacted watersheds. Nature Climate Change, 4(6), 481.

Benettin, P., Y. van der Velde, S. E. A. T. M. van der Zee, A. Rinaldo, and G. Botter (2013), Chloride circulation in a lowland catchment and the formulation of transport by travel time distributions, Water Resour. Res., 49, 4619-4632, doi:10.1002/wrcr.20309.

Bertoldi G., R. Rigon, T. M. Over (2006). Impact of watershed geomorphic characteristics on the energy and water budgets. J. Hydrometeorol., 7(3), 389-394.

Beven, K. J. (1989). Changing ideas in hydrology - The case of physically-based models. $J$. Hydrol., 105, 157-172.

Beven, K. J. (2001). How far can we go in distributed hydrological modelling? Hydrol. Earth Syst. Sci., 5, 1-12.

Beven, K. J. (2002). Towards an alternative blueprint for a physically based digitally simulated hydrologic response modelling system. Hydrol. Process., 16, 189-206.

Beven, K. J. (2006). On undermining the science? Hydrol. Process., 20, 3141-3146.

Beven, K. J. (2008). On doing better hydrological science. Hydrol. Process., 22, 3549-3553.

Beven, K. J., and H. L. Cloke (2012). Comment on "Hyperresolution global land surface modeling: Meeting a grand challenge for monitoring Earth's terrestrial water" by Eric F. Wood et al., Water Resour. Res., 48, W01801, doi:10.1029/2011WR010982.

Beven, K., and P. Germann (2013) Macropores and water flow in soils revisited, Water Resour. Res., 49, doi:10.1002/wrcr.20156.

Beven, K. J., and J. Freer (2001). Equifinality, data assimilation, and uncertainty estimation in mechanistic modelling of complex environmental systems using the glue methodology. J. Hydrol., 249, 11-29.

Bhatt G., M. Kumar, and C. J. Duffy (2014). A tightly coupled GIS and distributed hydrologic modeling framework. Environ. Modell. Softw., 62, 70-84, doi:10.1016/j.envsoft.2014.08.003

Bierkens M. F. P., Bell V. A., Burek P., Chaney N., Condon L., David C. H., de Roo A., Döll P., Drost N., Famiglietti J. S., Flörke M., Gochis D. J., Houser P., Hut R., Keune J., Kollet S., Maxwell R., Reager J. T., Samaniego L., Sudicky E., Sutanudjaja E. H., van de Giesen 
N., Winsemius H., and Wood E. F. (2015). Hyper-resolution global hydrological modelling: what is next? Hydrol. Process., 29, 310-320.

Blackmarr, W. A. (1995). Documentation of hydrologic, geomorphic, and sediment transport measurements on the Goodwin Creek Experimental Watershed, northern Mississippi, for the period 1982-1993. Research Report, Agricultural Research Service, U.S. Department of Agriculture, Washington, D.C

Bomblies, A., J. B. Duchemin, and E. A. B. Eltahir (2008). Hydrology of malaria: Model development and application to a Sahelian village. Water Resour. Res., 44, 12, W12445, doi:10.1029/2008WR006917.

Bonetti, S., G. Manoli, J.-C. Domec, M. Putti, M. Marani, and G. G. Katul (2015). The influence of water table depth and the free atmospheric state on convective rainfall predisposition. Water Resour. Res., 51, 2283-2297, doi:10.1002/2014WR016431.

Bras, R. L. (2009). Hydrology: No longer the forgotten science. American Geophysical Union, Fall Meeting, abstract H23K-02.

Bras, R. L., G. E. Tucker, and V. Teles (2003). Six myths about mathematical modeling in geomorphology. In Prediction in Geomorphology, vol. 135, edited by P. Wilcock and R. Iverson. American Geophysical Union Monograph; Washington; 63-83.

Bras, R., and P. S. Eagleson (1987). Hydrology, the forgotten earth science. EOS, 68, 227.

Brutsaert, W. H. (2005). Hydrology: An Introduction. Cambridge Univ. Press. Cambridge.

Camporese, M., C. Paniconi, M. Putti, and P. Salandin (2009a). Ensemble Kalman filter data assimilation for a process- based catchment scale model of surface and subsurface flow. Water Resour. Res., 45, W10421, doi:10.1029/2008WR007031.

Camporese, M., C. Paniconi, M. Putti, and P. Salandin (2009b), Comparison of data assimilation techniques for a coupled model of surface and subsurface flow, Vadose Zone $J ., 8,837-845$, doi:10.2136/vzj2009.0018.

Camporese, M., C. Paniconi, M. Putti, and S. Orlandini (2010). Surface-subsurface flow modeling with path-based runoff routing, boundary condition-based coupling, and assimilation of multisource observation data. Water Resour. Res., 46, W02512, doi:10.1029/2008WR007536.

Camporese, M., E. Daly, P. E. Dresel, and J. A. Webb (2014a), Simplified modeling of catchment-scale evapotranspiration via boundary condition switching, Adv. Water Resour., 69, 95-105, doi:10.1016/j.advwatres.2014.04.008. 
Camporese, M., D. Penna, M. Borga, and C. Paniconi (2014b). A field and modeling study of nonlinear storage-discharge dynamics for an Alpine headwater catchment. Water Resour. Res., 50, 806-822, doi:10.1002/2013WR013604.

Camporese, M., E. Daly, and C. Paniconi (2015), Catchment-scale Richards equation-based modeling of evapotranspiration via boundary condition switching and root water uptake schemes, Water Resour. Res., 51, 5756-5771, doi:10.1002/2015WR017139.

Castelletti, A., S. Galelli, M. Ratto, R. Soncini-Sessa, and P. Young (2012). A general framework for Dynamic Emulation Modelling in environmental problems. Environ. Modell. Softw., 34, 5-18.

814 Clark, M. P., D. Kavetski, and F. Fenicia (2011). Pursuing the method of multiple working hypotheses for hydrological modeling. Water Resour. Res., 47, W09301, doi:10.1029/2010WR009827.

Clark, M. P., Y. Fan, D. M. Lawrence, J. C. Adam, D. Bolster, D. J. Gochis, R. P. Hooper, M. Kumar, L. R. Leung, D. S. Mackay, R. M. Maxwell, C. Shen, S. C. Swenson, and X. Zeng (2015), Improving the representation of hydrologic processes in Earth System Models, Water Resour. Res., 51, 5929-5956, doi:10.1002/2015WR017096

Condon, L. E., Maxwell, R. M., and Gangopadhyay, S. (2013). The impact of subsurface conceptualization on land energy fluxes. Adv. Water Resour., 60, 188-203.

Crawford, N., and R. Linsley (1966). Digital simulation on hydrology: Stanford watershed model IV, Tech. Rep. 39, Stanford Univ., Palo Alto, CA.

Crowder, D. W., and P. Diplas (2002). Vorticity and circulation: spatial metrics for evaluating flow complexity in stream habitats. Canadian Journal of Fisheries and Aquatic Sciences, 59(4), 633-645.

Crowder, D. W., and P. Diplas (2006). Applying spatial hydraulic principles to quantify stream habitat. River Res. Appl., 22(1), 79-89.

Dall'Amico, M., Endrizzi, S., Gruber, S., and Rigon, R. (2011). A robust and energyconserving model of freezing variably-saturated soil. The Cryosphere, 5, 469-484.

Davison, J. H., Hwang, H.-T., Sudicky, E. A., and Lin, J. C. (2015). Coupled atmospheric, land surface, and subsurface modeling: Exploring water and energy feedbacks in threedimensions. Adv. Water Resour., 86(A), 73-85, doi:10.1016/j.advwatres.2015.09.002.

Della Chiesa S., Bertoldi G., Niedrist G., Obojes N., Endrizzi S., Albertson J. D., Wohlfahrt G., Hörtnagl L., and Tappeiner U. (2014), Modelling changes in grassland hydrological cycling along an elevational gradient in the Alps, Ecohydrol., 7, 1453-1473, doi: $10.1002 /$ eco. 1471 
839 Downer, C. W., and F. L. Ogden (2004). GSSHA: A model for simulating diverse streamflow 840 generating processes. J. Hydrol. Engrg., 9(3), 161-174.

841 Downer, C. W., B. E. Skahill, J. A. Graulau-Santiago, D. Weston, N. R. Pradhan, and A. R. 842 Byrd, (2015). Gridded Surface Subsurface Hydrologic Analysis modeling for analysis of 843 flood design features at the Picayune Strand Restoration Project, ERDC/CHL TR-15-X. 844 U.S. Army Engineer Research and Development Center, Vicksburg, MS.

845 Drewry, D. T., P. Kumar, S. Long, C. Bernacchi, X.-Z. Liang, and M. Sivapalan (2010). 846 Ecohydrological responses of dense canopies to environmental variability: 1. Interplay between vertical structure and photosynthetic pathway. J. Geophys. Res., 115, G04022, doi:10.1029/2010JG001340.

Eagleson P. S. (1991). Hydrologic science - a distinct geoscience. Reviews of Geophysics. 29(2), 237-248.

Ebel, B.A. and K. Loague. (2006). Physics-based hydrologic response simulation: Seeing through the fog of equifinality. Hydrological Processes 20, 2887-2900, doi: 10.1002/hyp.6388

Ebel B. A. and B. B. Mirus (2014). Disturbance hydrology: challenges and opportunities. Hydrol. Process. 28, 5140-5148, doi: 10.1002/hyp.10256

Ebel, B. A., K. Loague, W. E. Dietrich, D. R. Montgomery, R. Torres, S. P. Anderson, and T. W. Giambelluca. (2007a). Near-surface hydrologic response for a steep, unchanneled catchment near Coos Bay, Oregon: 1. Sprinkling experiments. American Journal of Science 307, 678-708, doi:10.2475/04.2007.02

860 Ebel, B. A., K. Loague, J. E. VanderKwaak, W. E. Dietrich, D. R. Montgomery, R. Torres, and S. P. Anderson. (2007b). Near-surface hydrologic response for a steep, unchanneled catchment near Coos Bay, Oregon: 2. Physics-based simulations. American Journal of Science 307, 709-748, doi:10.2475/04.2007.03

Ebel, B. A., B. B. Mirus, C. S. Heppner, J. E. VanderKwaak, and K. Loague (2009). Firstorder exchange coefficient coupling for simulating surface water-groundwater interactions: Parameter sensitivity and consistency with a physics-based approach. Hydrol. Process., 23(13), 1949-1959.

Ebel, B. A., K. Loague, D. R. Montgomery, and W. E. Dietrich (2008). Physics-based continuous simulation of long-term near-surface hydrologic response for the Coos Bay experimental catchment. Water Resour. Res., 44, W07417, doi:10.1029/2007WR006442.

Ek, M., B. Holtlsag (2004). Influence of soil moisture on boundary layer cloud development. 

parallel GSSHA. ERDC TR-13-8. U. S. Army Engineer Research and Development Center, Vicksburg, MS.

Endrizzi, S., Gruber, S., Dall'Amico, M., and Rigon, R. (2014). GEOtop 2.0: simulating the combined energy and water balance at and below the land surface accounting for soil freezing, snow cover and terrain effects. Geosci. Model Dev., 7, 2831-2857.

Ewen, J., Parkin G., and P. E. O'Connell, (2000). SHETRAN: Distributed river basin flow and transport modeling system, J. Hydrol. Engrg. 5(3), 250-258.

Falter, D., Schröter, K., Dung, N. V., Vorogushyn, S., Kreibich, H., Hundecha, Y., Apel H., and Merz, B. (2015). Spatially coherent flood risk assessment based on long-term continuous simulation with a coupled model chain. Journal of Hydrology, 524, 182-193.

Fatichi, S., V. Y. Ivanov, and E. Caporali (2012a). A mechanistic ecohydrological model to investigate complex interactions in cold and warm water-controlled environments: 1. Theoretical framework and plot-scale analysis. J. Adv. Model. Earth Syst., 4, M05002, doi:10.1029/2011MS000086.

Fatichi, S., V. Y. Ivanov, and E. Caporali (2012b). A mechanistic ecohydrological model to investigate complex interactions in cold and warm water-controlled environments: 2. Spatiotemporal analyses. J. Adv. Model. Earth Syst., 4, M05003, doi:10.1029/2011MS000087.

892 Fatichi, S., M. J. Zeeman, J. Fuhrer and P. Burlando (2014). Ecohydrological effects of management on subalpine grasslands: from local to catchment scale. Water Resour. Res., $50,148-164$.

Fatichi S., G. G. Katul, V. Y. Ivanov, C. Pappas, A. Paschalis, A. Consolo, J. Kim, and P. Burlando (2015a). Abiotic and biotic controls of soil moisture spatio-temporal variability and the occurrence of hysteresis. Water Resour. Res., doi: 10.1002/2014WR016102.

Fatichi S., S. Rimkus, P. Burlando, R. Bordoy, and P. Molnar (2015b). High-resolution distributed analysis of climate and anthropogenic changes on the hydrology of an Alpine catchment. Journal of Hydrology, 525, 362-382, doi:10.1016/j.jhydrol.2015.03.036

Flato G. M. (2011). Earth system models: an overview. WIREs Clim Change, 2:783-800. doi:

Forman, B.A., Vivoni, E. R., and Margulis, S. A. (2008). Evaluation of ensemble-based distributed hydrologic model response with disaggregated precipitation products. Water Resour. Res., 44, W12410, doi:10.1029/2008WR006983. 
906 Formetta G., Antonello A., Franceschi S., David O., and Rigon R. (2014). Hydrological

907

908

909

910

911

912

913

914

915

916

917

918

919

920

921

922

923

924

925

926

927

928

929

930

931

932

933

934

935

936

937

938 modelling with components: A GIS-based open-source framework. Environ. Modell. Softw., 55 190-200.

Frasson R. P. M., W. F. Krajewski (2013). Rainfall interception by maize canopy: Development and application of a process-based model. J. Hydrol., 489, 246-255.

Freeze R. A., and R. L. Harlan (1969). Blueprint for a physically-based digitally simulated, hydrologic response model. J. Hydrol., 9, 237-258.

Gamow, G. (1948). The origin of elements and the separation of galaxies. Physical Review, 74(4), 505-506.

Garen, D. C., and Moore, D. S. (2005). Curve number hydrology in water quality modeling: uses, abuses, and future directions. Journal of the American Water Resources Association, 41,2, 377-388.

Gasper, F., Goergen, K., Shrestha, P., Sulis, M., Rihani, J., Geimer, M., and Kollet, S. (2014). Implementation and scaling of the fully coupled Terrestrial Systems Modeling Platform (TerrSysMP v1.0) in a massively parallel supercomputing environment - a case study on JUQUEEN (IBM Blue Gene/Q). Geosci. Model Dev., 7, 2531-2543.

Gerke, H.H., and M.Th. van Genuchten (1993). A dual-porosity model for simulating the preferential movement of water and solutes in structured porous media, Water Resour. Res., 29, 305-319.

Gerwin, W., W. Schaaf, D. Biemelt, A. Fischer, S. Winter, and R. F. Hüttl (2009). The artificial catchment "Chicken Creek” (Lusatia, Germany)- A landscape laboratory for interdisciplinary studies of initial ecosystem development. Ecological Engineering, 35, 1786-1796.

Gleeson, T., L. Smith, N. Moosdorf, J. Hartmann, H. H. Dürr, A. H. Manning, L. P. H. van Beek, and A. M. Jellinek (2011). Mapping permeability over the surface of the Earth. Geophys. Res. Lett., 38, L02401, doi:10.1029/2010GL045565.

Gleeson, T., Wada, Y., Bierkens, M. F. P. and L. P. H. van Beek (2012). Water balance of global aquifers revealed by groundwater footprint. Nature, 488, 197-200.

Gleeson, T., N. Moosdorf, J. Hartmann and L. P. H. van Beek (2014). A glimpse beneath earth's surface: GLobal HYdrogeology MaPS (GLHYMPS) of permeability and porosity. Geophys. Res. Lett. 41, 3891-3898. doi:10.1002/2014GL059856

Gochis, D.J., W. Yu, and D. N. Yates, (2014). The WRF-Hydro model technical description and user's guide, version 2.0. NCAR Technical Document. 120 pages. Documentation, 
model code and ArcGIS Pre-processing Tools available online at: http://www.ral.ucar.edu/projects/wrf_hydro/.

941 Gochis, D.J., B. Cosgrove, W. Yu, E. Clark, D. Yates, A. Dugger, J. McCreight, L. Pan, Y. 942 Zhang, A. Rafeei-Nasab, L. Karsten, D. Cline, K. Sampson, A. Newman, A. Wood, and 943 M. Win-Gildenmeister (2015). Operational, hyper-resolution hydrologic modeling over 944 the contiguous U.S. using the multi-scale, multi-physics WRF-Hydro Modeling and Data Assimilation System. Abstract H52A-02, American Geophysical Union Fall Meeting, San Francisco, CA, USA.

Goodrich, D. C., L.J. Lane, R.M. Shillito, S.N. Miller, K.H. Syed, and D.A. Wooliser, Resour. Res., 33(12), 2951-2966.

Grathwohl, P., Rügner, H., Wöhling, T., Osenbrück, K., Schwientek, M., Gayler, S., Wollschläger, U., Selle, B., Pause, M., Delfs, J.-O., Grzeschik, M., Weller, U., Ivanov, M., Cirpka, O.A., Maier, U., Kuch, B., Nowak, W., Wulfmeyer, V., Warrach-Sagi, K., Streck, T., Attinger, S., Bilke, L., Dietrich, P., Fleckenstein, J.H., Kalbacher, T., Kolditz, O., reactors: a comprehensive approach for water fluxes and solute turnover. Environ. Earth Sci., 69(2), 317-333.

Gray, W. G., and S. Hassanizadeh (1991). Paradoxes and realities in unsaturated flow theory, Water Resour. Res., 27(8), 1847-1854.

Grayson, R. B., I. D. Moore, and T. A. McMahon (1992). Physically-based hydrologic modeling. 2. Is the concept realistic? Water Resour. Res., 28, 2659-2666.

Gupta, H. V., and G. S. Nearing (2014). Debates-The future of hydrological sciences: A (common) path forward? Using models and data to learn: A systems theoretic perspective on the future of hydrological science, Water Resour. Res., 50, 5351-5359, doi:10.1002/2013WR015096.

Guswa, A. J., K. A. Brauman, C. Brown, P. Hamel, B. L. Keeler and Stratton Sayre, S. (2014). Ecosystem services: Challenges and opportunities for hydrological modeling to support decision making. Water Resour. Res., 50(5), 4535-4544.

Hatzilacou, D., Kallis, G., Mexa, A., Coccosis, H. and Svoronou, E. (2007). Scenario workshops : A useful method for participatory water resources planning? Water Resour. Res., 43, W06414, doi:10.1029/2006WR004878.

Held I. M. and Soden B. J. (2006) Robust responses of the hydrological cycle to global warming. J Climate 19, 5686-5699. 
973

974

975

976

977

978

979

980

981

982

983

984

985

986

987

988

989

990

991

992

993

994

995

996

997

998

999

1000

1001

1002

1003

1004

Heppner, C. S., Loague, K. and VanderKwaak, J. E. (2007). Long-term InHM simulations of hydrologic response and sediment transport for the R-5 catchment. Earth Surf. Process. Landforms, 32, 1273-1292.

Hill, M. C. and Tiedeman C. R (2007). Effective groundwater model calibration: with analysis of data, sensitivities, predictions, and uncertainty, New York: Wiley and Sons.

Hinnell, A. C., T. P. A. Ferré, J. A. Vrugt, J. A. Huisman, S. Moysey, J. Rings, and M. B. Kowalsky (2010). Improved extraction of hydrologic information from geophysical data through coupled hydrogeophysical inversion. Water Resour. Res., 46, W00D40, doi:10.1029/2008WR007060.

Hobbie J. E., S. R. Carpenter, N. B. Grimm, J. R. Gosz and T. R. Seastedt (2003). The US Long Term Ecological Research program. BioScience, 53, 21-32.

Holländer, H. M., Blume, T., Bormann, H., Buytaert, W., Chirico, G. B., Exbrayat, J.-F., Gustafsson, D., Hölzel, H., Kraft, P., Stamm, C., Stoll, S., Blöschl, G., and Flühler, H (2009). Comparative predictions of discharge from an artificial catchment (Chicken Creek) using sparse data. Hydrol. Earth Syst. Sci., 13, 2069-2094.

Hopp, L., C. Harman, S. L. E. Desilets, C. B. Graham, J. J. McDonnell, and P. A. Troch (2009). Hillslope hydrology under glass: confronting fundamental questions of soil-waterbiota co-evolution at Biosphere 2. Hydrol. Earth Syst. Sci, 13, 2105-2118.

Hornbeck, J. W., M. B. Adams, E. S. Corbett, E. S. Verry, and J. A. Lynch (1993). Longterm impacts of forest treatments on water yield: A summary for northeastern USA. $J$. Hydrol., 150, 323-344.

Hubbard, S. S. and Y. Rubin (2000). Hydrogeological parameter estimation using geophysical data: a review of selected techniques. J. Contaminant Hydrol., 45(1-2), 3-34.

Hughes, J. D., and J. T. White (2013). Use of general purpose graphics processing units with MODFLOW. Groundwater, 51(6), 833-846.

Huntington, J. L. and R. G. Niswonger (2012). Role of surface-water and groundwater interactions on projected summertime streamflow in snow dominated regions: An integrated modeling approach. Water Resour. Res., 48, W11524, doi:10.1029/2012WR012319.

Huxman, T., P. Troch, J. Chorover, D. D. Breshears, S. Saleska, X. Z. J. Pelletier, and J. Espeleta (2009). The hills are alive: Earth science in a controlled environment. Eos Transactions AGU, 34(90), 120. 
Hwang, H.-T., Y.-J. Park, E.A. Sudicky, and P. A. Forsyth (2014). A parallel computational framework to solve flow and transport in integrated surface-subsurface hydrologic systems. Environ. Modell. Softw. 61, 39-58.

1008

Hwang, H.-T., Y.-J. Park, S.K. Frey, S.J. Berg, and E.A. Sudicky (2015). A simple iterative method for estimating evapotranspiration with integrated surface/subsurface flow models. J. Hydrol., 531(3), 949-959, doi:10.1016/j.jhydrol.2015.10.003.

Hwang, T., L. E. Band, J. M. Vose, and C. Tague (2012). Ecosystem processes at the watershed scale: Hydrologic vegetation gradient as an indicator for lateral hydrologic connectivity of headwater catchments. Water Resour. Res., 48, W06514, doi:10.1029/2011WR011301.

1016

Hyndman, D. W., Day-Lewis, F. D., and Singha, K. (2007). Subsurface hydrology: data integration for properties and processes, American Geophysical Union Monograph, vol. 171, pp. 253.

Ivanov V. Y., S. Fatichi, G. D. Jenerette, J. F. Espeleta, P. A. Troch and T. E. Huxman, (2010). Hysteresis of soil moisture spatial heterogeneity and the "homogenizing" effect of vegetation. Water Resour. Res., 46, W09521, doi:10.1029/2009WR008611.

1022

Ivanov, V. Y., R. L. Bras, and E. R. Vivoni (2008a). Vegetation-hydrology dynamics in complex terrain of semiarid areas. I: A mechanistic approach to modeling dynamic feedbacks. Water Resour. Res., 44, W03429, doi:10.1029/2006WR005588

Ivanov, V.Y., Bras, R.L., and Vivoni, E.R. (2008b). Vegetation-hydrology dynamics in complex terrain of semiarid areas: II. Energy-water controls of vegetation spatio-temporal dynamics and topographic niches of favorability. Water Resour. Res., 44, W03430, doi:10.1029/2006WR005595.

Jana, R. B., and B. P. Mohanty (2012), On topographic controls of soil hydraulic parameter scaling at hillslope scales, Water Resour. Res., 48, W02518, doi:10.1029/2011WR011204.

Johnson, B. E., Z. Zhang, and C. W. Downer (2013). Watershed scale physically based water flow, sediment and nutrient dynamic modeling system, in Landscape Ecology for

Jones J. A. (2000). Hydrologic processes and peak discharge response to forest removal, regrowth, and roads in 10 small experimental basins, western Cascades, Oregon. Water Resour. Res., 36, 2621-2642. 
Kalyanapu A. J., S. Shankar, E. R. Pardyjak, D. R. Judi, S. J. Burian (2011). Assessment of GPU computational enhancement to a 2D flood model. Environ. Modell. Softw., 26(8) 1009-1101.

1040 Kendall, C., J. J. McDonnell, and W. Gu (2001). A look inside 'black box' hydrograph separation models: a study at the Hydrohill catchment. Hydrol. Process., 15, 1877-1902.

Kerkez, B., S. D. Glaser, R. C. Bales, and M. W. Meadows (2012). Design and performance of a wireless sensor network for catchment-scale snow and soil moisture measurements. Water Resour. Res., 48, W09515, doi:10.1029/2011WR011214.

Kerr, R. (1963). Gravitational field of a spinning mass as an example of algebraically special metrics. Phys. Review Lett., 11, 237-238.

Kim, J., A. Warnock, V. Y. Ivanov, and N. D. Katopodes (2012a). Coupled modeling of hydrologic and hydrodynamic processes including overland and channel flow. Adv. Water Resour., 37, 104-126.

Kim, J., V. Y. Ivanov, and N. D. Katopodes (2012b). Hydraulic resistance to overland flow on surfaces with partially submerged vegetation, Water Resour. Res., 48, W10540, doi:10510.11029/12012WR012047.

Kim, J. A., V. Y. Ivanov, and N. D. Katopodes (2013). Modeling erosion and sedimentation coupled with hydrological and overland flow processes at the watershed scale, Water Resour. Res., 49, 5134-5154.

Kim, J., and V. Y. Ivanov (2014). On the nonuniqueness of sediment yield at the catchment scale: The effects of soil antecedent conditions and surface shield. Water Resour. Res., 50(2), 1025-1045.

Kim, J., and V. Y. Ivanov (2015). A holistic, multi-scale dynamic downscaling framework for climate impact assessments and challenges of addressing finer-scale watershed dynamics. J. Hydrol., 522, 645-660.

Kleidon, A., S. Schymanski, and M. Stieglitz (2009), Thermodynamics, irreversibility and optimality in land surface hydrology, in Bioclimatology and natural hazards, Strelcova, K., Matyas, C., eds.; Springer: Dordrecht, Netherlands.

Klemeš, V. (1986). Dilettantism in hydrology: Transition or destiny? Water Resour. Res.,

1067 Klemeš, V. (1988). A hydrological perspective. J. Hydrol., 100, 3-28.

1068 Kolditz O., S. Bauer, L. Bilke, N. Böttcher, J.O. Delfs, T. Fischer, U. J. Görke, et al. (2012). 1069 OpenGeoSys: an open-source initiative for numerical simulation of thermo-hydro- 

599.

Kollet, S. J., and R. M. Maxwell (2006). Integrated surface-groundwater flow modeling: A free-surface overland flow boundary condition in a parallel groundwater flow model. $A d v$. Water Resour., 29(7), 945-958.

Kollet, S. J., and R. M. Maxwell (2008a). Capturing the influence of groundwater dynamics on land surface processes using an integrated, distributed watershed model. Water Resour. Res., 44, W02402, doi:10.1029/2007WR006004.

Kollet, S. J., and R. M. Maxwell (2008b). Demonstrating fractal scaling of baseflow residence time distributions using a fully-coupled groundwater and land surface model. Geophys. Res. Lett., 35, L07402, doi:10.1029/2008GL033215.

Kollet, S. J., Maxwell, R. M., Woodward, C. S., Smith, S., Vanderborght, J., Vereecken, H., and Simmer, C. (2010). Proof of concept of regional scale hydrologic simulations at hydrologic resolution utilizing massively parallel computer resources. Water Resour. Res., 46, W04201, doi:10.1029/2009WR008730.

Koutsoyiannis, D. (2010). A random walk on water. Hydrol. Earth Syst. Sci., 14, 586-601. using ground-penetrating radar and hydrological measurements during transient flow in the vadose zone. Adv. Water Resour., 27(6), 583-599.

Kuchment L. S. and A. N. Gelfan (1991) Dynamic-stochastic models of rainfall and snowmelt runoff formation, Hydrological Sciences Journal, 36:2, 153-169, DOI:10.1080/02626669109492496

Kuchment, L. S., E. L. Muzylev, and Z. P. Startseva (1996), The effects of land surface heterogeneities on the hydrological cycle. Theoretical and Applied Climatology, 55, 185192

Kuchment, L.S., A. N. Gelfan, and V. N. Demidov (2000). A distributed model of runoff generation in the permafrost regions. J. Hydrol., 240, 1-22.

Kumar, M., Bhatt, G., and C. J. Duffy (2010). An object-oriented shared data model for GIS and distributed hydrologic models. Int. J. Geogr. Inf. Sci., 24(7), 1061-1079.

Kumar, M., C. J. Duffy, and K. M. Salvage (2009). A second order accurate, finite volume based, integrated hydrologic modeling (FIHM) framework for simulation of surface and subsurface flow. Vadose Zone J., 8(4), 873-890. 
1102 Lacasta, A., Morales-Hernández, M., Murillo, J., and García-Navarro, P. (2015). GPU 1103 implementation of the 2D shallow water equations for the simulation of rainfall/runoff events. Environmental Earth Sciences, 1-11.

1105 Lai, W., F. L. Ogden, R. C. Steinke, and C. A. Talbot (2015), An efficient and guaranteed 1106 stable numerical method for continuous modeling of infiltration and redistribution with a 1107 shallow dynamic water table, Water Resour. Res., 51, doi:10.1002/2014WR016487.

1108 Le, P. V. V., P. Kumar and D. T. Drewry (2011). Implications for the hydrologic cycle under 1109 climate change due to the expansion of bioenergy crops in the Midwestern United States. $1110 \quad$ Proc. Natl. Acad. Sci. 108, 15085-15090.

1111 Le, P. V. V., P. Kumar, A. J. Valocchi, and H.-V. Dang, (2015): GPU-based high1112 performance computing for integrated surface-sub-surface flow modeling Environ. $1113 \quad$ Modell. Softw., 73, 1-13, doi:10.1016/j.envsoft.2015.07.015

1114 Lehning, M., Völksch, I., Gustafsson, D., Nguyen, T., Stähli, M., and Zappa, M. (2006). 1115 ALPINE3D: a detailed model of mountain surface processes and its application to snow 1116 hydrology. Hydrol. Process., 20, 2111-2128.

1117 Levin, S. (1999). Fragile Dominion: Complexity and the Commons, Perseus Publishing, 1118 Cambridge MA, USA.

1119 Li, Q., Unger, A. J. A., Sudicky, E. A., Kassenaar, D., Wexler, E. J., and Shikaze, S. (2008). 1120 Simulating the multi-seasonal response of a large-scale watershed with a 3D physically1121 based hydrologic model. J. Hydrol., 357(3), 317-336.

1122 Lin N., K. Emanuel, M. Oppenheimer and E. Vanmarcke (2012). Physically based 1123 assessment of hurricane surge threat under climate change. Nature Climate Change, 2, $1124 \quad 462-467$.

1125 Loague, K., and J. E. VanderKwaak (2004). Physics-based hydrologic response simulation: 1126 platinum bridge, 1958 Edsel, or useful tool. Hydrol. Process., 18, 2949-2956.

1127 Loague, K., C. S. Heppner, B. A. Ebel, and J. E. VanderKwaak (2010). The quixotic search 1128 for a comprehensive understanding of hydrologic response at the surface: Horton, Dunne, 1129 Dunton, and the role of concept development simulations. Hydrol. Process., 24, 2499$1130 \quad 2505$.

1131 Loague, K., C. S. Heppner, B. B. Mirus, B. A. Ebel, Q. Ran, A. E. Carr, S. H. BeVille, and J. 1132 E. VanderKwaak (2006). Physics-based hydrologic-response simulation: foundation for 1133 hydroecology and hydrogeomorphology. Hydrol. Process., 20, 1231-1237. 
1134 Lott, P. A., H. F. Walker, C. S. Woodward, and U. M. Yang, (2012) An accelerated Picard 1135 method for nonlinear systems related to variably saturated flow. Adv. Water Resour., 38, 92-101 doi:10.1016/j.advwatres.2011.12.013

1137 Luce, C. H, Tarboton, D. G, Cooley, K. R., (1998). The influence of the spatial distribution of 1138 snow on basin-averaged snowmelt. Hydrol. Process., 12(10-11), 1671-1683.

1139 Mahmood, T. H. and Vivoni, E. R. (2011). A climate-induced threshold in hydrologic

Mandelbrot, B. (1967). How long is the coast of Britain? statistical self-similarity and fractional dimension. Science, 156(3775), 636-638.

1144 Manning, L. J., J. W. Hall, H. J. Fowler, C. G. Kilsby, and C. Tebaldi (2009). Using 1145 probabilistic climate change information from a multimodel ensemble for water resources assessment. Water Resour. Res., 45, W11411, doi:10.1029/2007WR006674.

Markstrom, S.L., Niswonger, R.G., Regan, R.S., Prudic, D.E., and Barlow, P.M., (2008). GSFLOW-Coupled Ground-water and Surface-water FLOW model based on the integration of the Precipitation-Runoff Modeling System (PRMS) and the Modular Ground-Water Flow Model (MODFLOW-2005): U.S. Geological Survey Techniques and Methods 6-D1, $240 \mathrm{pp}$.

Mascaro, G., Vivoni, E. R. and Deidda, R. (2010). Implications of ensemble quantitative precipitation forecast errors on distributed streamflow forecasting. J. Hydrometeorol.,

Mascaro, G. and Vivoni, E. R. (2012). Utility of coarse and downscaled soil moisture products at L-band for hydrologic modeling at the catchment scale. Geophys. Res. Lett., 39, L10403, doi:10.1029/2012GL051809.

Mascaro, G., Vivoni, E.R., and Méndez-Barroso, L.A. (2015). Hyperresolution hydrologic modeling in a regional watershed and its interpretation using Empirical Orthogonal Functions. Adv. Water Resour., 83, 190-206.

Massey, T. C., Pradhan, N.R., Byrd, A. R., and Cresitello, D. E. (2013). USACE-ERDC Coastal Storm Modelling Systems in Support of Hurricane Sandy Operations, Flood Risk Management Newsletter, 6(4) 2-3.

Maxwell, R. M., and S. J. Kollet (2008). Interdependence of groundwater dynamics and landenergy feedbacks under climate change. Nat. Geosci., 1, 665-669. 
1166 Maxwell, R. M., et al. (2014). Surface-subsurface model intercomparison: A first set of 1167 benchmark results to diagnose integrated hydrology and feedbacks. Water Resour. Res., 50, 1531-1549, doi:10.1002/2013WR013725.

1169 Maxwell, R. M., F. K. Chow, and S. J. Kollet (2007). The groundwater-land-surface1170 atmosphere connection: Soil moisture effects on the atmospheric boundary layer in fully1171 coupled simulations. Adv. Water Resour., 30, 2447-2466.

1172 Maxwell, R. M., J. D. Lundquist, J. D. Mirocha, S. G. Smith, C. S. Woodward, and A. F. B. 1173 Tompson (2011). Development of a coupled groundwater-atmospheric model. Mon. Weat. Rev., 139, 96-116.

Maxwell R. M., L. E. Condon, and S. J. Kollet (2015). A high-resolution simulation of groundwater and surface water over most of the continental US with the integrated hydrologic model ParFlow v3. Geosci. Model Dev., 8, 923-937, doi:10.5194/gmd-8-9232015

McDonnell, J. J., M. Sivapalan, K. Vaché, S. Dunn, G. Grant, R. Haggerty, C. Hinz, R. Hooper, J. Kirchner, M. L. Roderick, J. Selker, and M. Weiler (2007). Moving beyond heterogeneity and process complexity: A new vision for watershed hydrology. Water Resources Research, 43, W07301, doi:10.1029/2006WR005467.

Melillo, J. M., T. C. Richmond and G. W. Yohe, (2014). Eds., Highlights of Climate Change Impacts in the United States: The Third National Climate Assessment. U.S. Global Change Research Program, 148 pp.

Mendez-Barroso, L. A., Vivoni, E. R., Robles-Morua, A., Mascaro, G., Yepez, E. A., Rodriguez, J. C., Watts, C. J., Garatuza-Payan, J., and Saiz-Hernandez, J. (2014). A modeling approach reveals differences in evapotranspiration and its partitioning in two semiarid ecosystems in northwest Mexico. Water Resour. Res., 50(4), 3229-3252.

Mendicino, G., A. Senatore, G. Spezzano, and S. Straface, (2006). Three-dimensional unsaturated flow modeling using cellular automata. Water Resour. Res., 42, W11419 doi:10.1029/2005WR004472

Mendoza, P. A., M. P. Clark, M. Barlage, B. Rajagopalan, L. Samaniego, G. Abramowitz, and H. Gupta (2015). Are we unnecessarily constraining the agility of complex processbased models? Water Resour. Res., 51, 716-728, doi:10.1002/2014WR015820.

1197 Lettenmaier, and R. J. Stouffer (2008). Stationarity is dead: whither water management? Science, 319, 573-574. 
1199 Milly, P. C. D., J. Betancourt, M. Falkenmark, R. M. Hirsch, Z. W. Kundzewicz, D. P. 1200 Lettenmaier, R. J. Stouffer, M. D. Dettinger, and V. Krysanova (2015), On Critiques of 1201 “Stationarity is Dead: Whither Water Management?', Water Resour. Res., 51, 1202 doi:10.1002/2015WR017408.

1203 Mirus, B. B., and K. Loague (2013). How runoff begins (and ends): Characterizing 1204 hydrologic response at the catchment scale. Water Resour. Res., 49, 1205 doi:10.1002/wrcr.20218.

1206 Mirus, B. B. (2015). Evaluating the Importance of Characterizing Soil Structure and Horizons in Parameterizing a Hydrologic Process Model. Hydrol. Process., HYP-140716.R1.

Mirus, B. B., B. A. Ebel, C. S. Heppner, and K. Loague (2011a). Assessing the detail needed to capture rainfall-runoff dynamics with physics-based hydrologic response simulation. Water Resour. Res., 47, W00H10, doi:10.1029/2010WR009906.

Mirus, B. B., K. Loague, N. C. Cristea, S. J. Burges, and S. K. Kampf (2011b). A synthetic hydrologic-response dataset. Hydrol. Process., 25, 3688-3692.

Moffett, K. B., Gorelick, S. M., McLaren, R. G., and Sudicky, E. A. (2012). Salt marsh ecohydrological zonation due to heterogeneous vegetation-groundwater-surface water interactions. Water Resour. Res., 48, W02516, doi:10.1029/2011WR010874.

Montanari, A. (2005). Large sample behaviors of the generalized likelihood uncertainty estimation (GLUE) in assessing the uncertainty of rainfall runoff simulations. Water Resour. Res., 41, W08406, doi:10.1029/2004WR003826.

Montanari, A. (2007). What do we mean by 'uncertainty'? The need for a consistent wording about uncertainty assessment in hydrology. Hydrol. Process., 21, 841-845.

Montanari, A., and D. Koutsoyiannis (2012). A blueprint for process-based modeling of uncertain hydrological systems. Water Resour. Res., 48, W09555, doi:10.1029/2011WR011412.

Moreno, H. A., E. R. Vivoni, and D. J. Gochis (2013). Limits to flood forecasting in the Colorado Front Range for two summer convection periods using radar nowcasting and a distributed hydrologic model. J. Hydrometeorol., 14(4), 1075-1097. Iturbe (2008). Neutral metacommunity models predict fish diversity patterns in Mississippi-Missouri basin. Nature, 453, 220-223. 
1231 Neuweiler, I., and O. A. Cirpka, (2005). Homogenization of Richards equation in 1232 permeability fields with different connectivities. Water Resour. Res., 41, W02009 doi:10.1029/2004WR00332

1234 Ng, G.-H. C., D. R. Bedford, and D. M. Miller (2014). A mechanistic modeling and data 1235 assimilation framework for Mojave Desert ecohydrology. Water Resour. Res., 50, 46624685, doi:10.1002/2014WR015281

Nicolau, J.-M. (2002). Run-off generation and routing on artificial slopes in a Mediterraneancontinental environment: the Teruel coalfield, Spain. Hydrol. Process., 16, 631-647.

Niedzialek, J.M, and F.L. Ogden (2004). Numerical investigation of saturated source area behavior at the small catchment scale. Adv. Water Resour. 27, 925-936.

Niessner, J., and S. M. Hassanizadeh (2008), A model for two-phase flow in porous media including fluid-fluid interfacial area, Water Resour. Res., 44, W08439, doi:10.1029/2007WR006721

Nimmo, J. R. (2012), Preferential flow occurs in unsaturated conditions. Hydrol. Process., 26: 786-789. doi:10.1002/hyp.8380

Niswonger, R. G., K. K. Allander and A. E. Jeton (2014). Collaborative modelling and integrated decision support system analysis of a developed terminal lake basin. J. Hydrol., $517,521-537$.

Niu, G.-Y., C. Paniconi, P. A. Troch, R. L. Scott, M. Durcik, X. Zeng, T. Huxman, and D. C. Goodrich (2014a). An integrated modelling framework of catchment-scale ecohydrological processes: 1. Model description and tests over an energy-limited watershed. Ecohydrol., 7, 427-439.

Niu, G.-Y., Pasetto, D., Scudeler, C., Paniconi, C., Putti, M., Troch, P. A., DeLong, S. B., Dontsova, K., Pangle, L., Breshears, D. D., Chorover, J., Huxman, T. E., Pelletier, J., Saleska, S. R., and Zeng, X. (2014b). Incipient subsurface heterogeneity and its effect on overland flow generation - insight from a modeling study of the first experiment at the Biosphere 2 Landscape Evolution Observatory. Hydrol. Earth Syst. Sci., 18, 1873-1883.

Niu, J., C. Shen, S.-G. Li, and M. S. Phanikumar (2014c). Quantifying storage changes in regional Great Lakes watersheds using a coupled subsurface-land surface process model and GRACE, MODIS products. Water Resour. Res., 50(9), 7359-7377.

Niu, J., and M. S. Phanikumar (2015). Modeling watershed-scale solute transport using an integrated, process-based hydrologic model with applications to bacterial fate and transport. J. Hydrol. 529, 35-48. doi:10.1016/j.jhydrol.2015.07.013 
1264 Ogden, F.L., and D.R. Dawdy, (2003). Peak discharge scaling in a small Hortonian watershed. J. Hydrol. Engrg., 8(2):64-73.

1266 Ogden, F.L., N.R. Pradhan, C.W. Downer, J.A. Zahner (2011). Relative importance of 1267 impervous area, drainage density, width function, and subsurface storm drainage on flood 1268 runoff from an urbanized catchment. Water Resour. Res., 47, W12503, 1269 doi:10.1029/2011WR010550.

1270 Ogden, F. L., and R.F. Stallard, (2013). Land use effects on ecosystem service provisioning in tropical watersheds, still an important unsolved problem. Proceedings of the National Academy of Sciences of the United States of America, 110(52), E5037. doi:10.1073/pnas.1314747111

Ogden, F.L., T.D. Crouch, R.F. Stallard, and J.S. Hall (2013). Effect of land cover and use on dry season river runoff, runoff efficiency, and peak storm runoff in the seasonal tropics of Central Panama. Water Resour. Res., 49, 8443-8462, doi:10.1002/2013WR013956.

Ogden, F.L., W. Lai, R.C. Steinke, (2015a). ADHydro- Quasi-3D high-performance hydrologic model. Proc. SEDHYD 2015, 3rd Joint Federal Interagency Conference (10th Federal Interagency Sedimentation Conference and 5th Federal Interagency Hydrologic Modeling Conference) April 19-23, Reno, Nevada.

Ogden, F. L., W. Lai, R. C. Steinke, J. Zhu, C. A. Talbot, and J. L. Wilson (2015b), A new general 1-D vadose zone solution method, Water Resour. Res., 51, doi:10.1002/2015WR017126.

Ogden, F. L., W. Lai, R. C. Steinke, and J. Zhu (2015c), Validation of finite water-content vadose zone dynamics method using column experiments with a moving water table and applied surface flux, Water Resour. Res., doi:10.1002/2014WR016454.

Panciera, R., Walker, J.P. Jackson, T.J. Gray, D.A. Tanase, M.A. Dongryeol Ryu, Monerris, A., Yardley, H., Rudiger, C., Xiaoling Wu, Ying Gao, and Hacker, J.M. (2014). The Soil Moisture Active Passive Experiments (SMAPEx): Toward soil moisture retrieval from the SMAP Mission. IEEE T. Geosci. Remote Sensing, 52(1), 490-507.

Panday, S., and P. S. Huyakorn (2004). A fully coupled physically-based spatially-distributed model for evaluating surface/subsurface flow. Adv. Water Resour., 27(4), 361-382.

Paniconi, C., and M. Putti (1994). A comparison of Picard and Newton iteration in the numerical solution of multidimensional variably saturated flow problems, Water Resour. Res., 30, 3357-3374.

Paniconi, C., and M. Putti (2015), Physically based modeling in catchment hydrology at 50: Survey and outlook, Water Resour. Res., 51, doi:10.1002/2015WR017780. 
1298 Paola, C., E. Foufoula-Georgiou, W. E. Dietrich, M. Hondzo, D. Mohrig, G. Parker, M. E. 1299 Power, I. Rodriguez-Iturbe, V. Voller, and P. Wilcock (2006). Toward a unified science of 1300 the Earth's surface: Opportunities for synthesis among hydrology, geomorphology, 1301 geochemistry, and ecology. Water Resour. Res., 42, W03S10, 1302 doi:10.1029/2005WR00433.

1303 Pappas C., S. Fatichi, S. Leuzinger, A. Wolf, and P. Burlando (2013). Sensitivity analysis of a process-based ecosystem model: pinpointing parameterization and structural issues. $J$. Geophys. Res., 118, 2, 505-528.

Park, Y. J., Sudicky, E. A., Panday, S., and Matanga, G. (2009). Implicit subtime stepping for solving nonlinear flow equations in an integrated surface-subsurface system. Vadose Zone J., 8(4), 825-836.

Park, Y. J., Sudicky, E. A., Panday, S., Sykes, J. F., and Guvanasen, V. (2008). Application of implicit sub-time stepping to simulate flow and transport in fractured porous media. Adv. Water Resour., 31(7), 995-1003.

Park, Y.-J., E. A. Sudicky, A. E. Brookfield, and J. P. Jones (2011). Hydrologic response of catchments to precipitation: Quantification of mechanical carriers and origins of water. Water Resour. Res., 47, W12515, doi:10.1029/2010WR010075.

Parker, D. C., S. M. Manson, M. A. Janssen, M. J. Hoffman, and P. Deadman (2003). Multiagent systems for the simulation of land-use and land-cover change: A review. Annals of the Association of American Geographers, 93(2), 314-337.

Pasetto, D., M. Camporese and M. Putti (2012). Ensemble Kalman filter versus particle filter for a physically-based coupled surface-subsurface model. Adv. Water Resour., 47, 1-13.

Pasetto, D., Putti, M., and Yeh, W. W. G. (2013). A reduced-order model for groundwater flow equation with random hydraulic conductivity: Application to Monte Carlo methods. Water Resour. Res., 49(6), 3215-3228.

Pau, G. S. H., C. Shen, W. J. Riley and Y. Liu (2016). Accurate and efficient prediction of fine-resolution hydrologic and carbon dynamic simulations from coarse-resolution models. Water Resour. Res. doi:10.1002/2015WR017782

Pierini N. A., E. R. Vivoni, A. Robles-Morua, R. L. Scott and M. A. Nearing (2014). Using observations and a distributed hydrologic model to explore runoff thresholds linked with mesquite encroachment in the Sonoran Desert. Water Resour. Res., 50(10), 8191-8215

Pimm, S. L. (1984). The complexity and stability of ecosystems. Nature, 307(5949), 321326. 
1331 Piras, M., Mascaro, G., Deidda, R., and Vivoni, E. R. (2014). Quantification of hydrologic

1332

1333

1334

1335

1336

1337

1338

1339

1340

1341

1342

1343

1344

1345

1346

1347

1348

1349

1350

1351

1352

1353

1354

1355

1356

1357

1358

1359

1360

1361

1362

1363 impacts of climate change in a Mediterranean basin in Sardinia, Italy, through highresolution simulations. Hydrol. Earth Syst. Sci., 18(12), 5201-5217.

Pomeroy, J. W., D. M. Gray, T. Brown, N. R. Hedstrom, W. L. Quinton, R. J. Granger, and S. K. Carey (2007). The Cold Regions Hydrological Model, a platform for basing process representation and model structure on physical evidence. Hydrol. Process., 21(19), 26502667.

Pradhan, N. R., C. W. Downer, and B. E. Johnson (2014). A physics based hydrologic modeling approach to simulate non-point source pollution for the purposes of calculating TMDLs and designing abatement measures." Chapter 9, Practical aspects of computational chemistry III , J. Leszczynski and M. K. Shukla, eds., Springer, New York, 249-282.

Qu, Y., and C. J. Duffy (2007). A semidiscrete finite volume formulation for multiprocess watershed simulation. Water Resour. Res., 43, W08419, doi:10.1029/2006WR005752.

Rahman, M., M. Sulis, and S. J. Kollet (2014). The concept of dual-boundary forcing in land surface-subsurface interactions of the terrestrial hydrologic and energy cycles. Water Resour. Res., 50, 8531-8548, doi:10.1002/2014WR015738.

Raia, S., Alvioli, M., Rossi, M., Baum, R.L., Godt, J.W., and Guzzetti, R. (2014), Improving predictive power of physically based rainfall-induced shallow landslide models: a probabilistic approach, Geoscientific Model Development, 7, 495-514, doi:10.5194/gmd-7495-2014.

Ran Q., D.Y. Su, X. Fu, and G. Wang (2013). A physics-based hydro-geomorphologic simulation utilizing cluster parallel computing. Science China Technological Sciences, 56(8), 1883-1895.

Razavi, S., B. A. Tolson, and D. H. Burn (2012a). Numerical assessment of metamodelling strategies in computationally intensive optimization. Env. Model. Soft., 34, 67-86.

Razavi, S., B. A. Tolson, and D. H. Burn (2012b). Review of surrogate modeling in water resources. Water Resour. Res., 48, W07401, doi:10.1029/2011WR011527.

Renard, B., D. Kavetski, G. Kuczera, M. Thyer, and S. W. Franks (2010), Understanding predictive uncertainty in hydrologic modeling: The challenge of identifying input and structural errors, Water Resour. Res., 46, W05521, doi:10.1029/2009WR008328.

Restrepo, P. J., and R. L. Bras (1985). A view of maximum-likelihood estimation with large conceptual hydrologic models. Applied Mathematics and Computation, 17(4), 375-403. 
1364 Rigon, R., G. Bertoldi, and T. M. Over (2006). GEOtop: A distributed hydrological model with coupled water and energy budgets. J. Hydrometeorol., 7(3), 371-388.

1366 Rihani, J. F., R. M. Maxwell, and F. K. Chow (2010). Coupling groundwater and land surface 1367 processes: Idealized simulations to identify effects of terrain and subsurface heterogeneity 1368 on land surface energy fluxes. Water Resour. Res., 46, W12523, doi:10.1029/2010WR009111.

Rihani, J. F., F. K. Chow, and R. M. Maxwell (2015), Isolating effects of terrain and soil moisture heterogeneity on the atmospheric boundary layer: Idealized simulations to diagnose land atmosphere feedbacks, J. Adv. Model. Earth Syst., 7, 915-937, doi:10.1002/2014MS000371.

Rinaldo, A. (2009). Il governo dell'acqua. Ambiente naturale e ambiente costruito, Marsilio Editore, Venezia, (In Italian).

Rinehart, A. J., E. R. Vivoni, and P. D. Brooks (2008). Effects of vegetation, albedo and solar radiation sheltering on the distribution of snow in the Valles Caldera, New Mexico. Ecohydrol., 1(3), 253-270.

Robinson, D. A., Binley, A., Crook, N., Day-Lewis, F. D., Ferré, T. P. A., Grauch, V. J. S., Knight, R., Knoll, M., Lakshmi, V., Miller, R., Nyquist, J., Pellerin, L., Singha, K. and Slater, L. (2008). Advancing process-based watershed hydrological research using nearsurface geophysics: a vision for, and review of, electrical and magnetic geophysical methods. Hydrol. Process., 22, 3604-3635.

Robles-Morua, A., Mayer, A. S., Auer, M. T. and Vivoni, E. R. (2012). Modeling riverine pathogen fate and transport in Mexican rural communities and its associated public health implications. J. Env. Management, 113, 61-70.

Rodriguez-Iturbe, I., and A. Rinaldo (1997). Fractal River Basins: Chance and SelfOrganization, Cambridge University Press. Cambridge UK.

Samaniego, L., R. Kumar, and S. Attinger (2010). Multiscale parameter regionalization of a grid-based hydrologic model at the mesoscale Water Resour. Res., 46(5) W05523.

Santanello, J., C. Peters-Lidard, and S. Kumar (2011). Diagnosing the sensitivity of local land-atmosphere coupling via the soil moisture-boundary layer interaction. $J$. Hydrometeorol., 12(5), 766-786.

Schwarzschild, K. (1916). On the gravitational field of a sphere of incompressible fluid 1396 according to Einstein's theory, Sitzungsber. Preuss. Akad. Wiss. Berlin (Math. Phys.), 424434. 
Seibert, J., and J. J. McDonnell, (2002). On the dialog between experimentalist and modeler in catchment hydrology: Use of soft data for multicriteria model calibration. Water Resour. Res., 38(11), 1241. doi:10.1029/2001WR000978.

Seibert, J. (2003), Reliability of model predictions outside calibration conditions, Nord. Hydrol., 34, 477-492.

Senarath, S.U.S., F.L. Ogden, C.W. Downer and H.O. Sharif (2000). On the calibration and verification of two-dimensional distributed, Hortonian, continuous watershed models, Water Resour. Res., 36(6) 1495-1510.

Shao, W., Bogaard, T. A., Bakker, M., and Greco, R. (2015). Quantification of the influence of preferential flow on slope stability using a numerical modelling approach, Hydrol. Earth Syst. Sci., 19, 2197-2212, doi:10.5194/hess-19-2197-2015..

Shen, C., and M. S. Phanikumar (2010). A process-based, distributed hydrologic model based on a large-scale method for surface-subsurface coupling. Adv. Water Resour., 33, 15241541.

Shen, C., J. Niu, and M. S. Phanikumar (2013). Evaluating controls on coupled hydrologic and vegetation dynamics in a humid continental climate watershed using a subsurface-land surface processes model. Water Resour. Res., 49, doi:10.1002/wrcr.20189.

Shen, C., J. Niu, and K. Fang (2014). Quantifying the effects of data integration algorithms on the outcomes of a subsurface-land surface processes model, Environ. Modell. Softw., 59, 146-161, doi:10.1016/j.envsoft.2014.05.006

Shen, C., W.J. Riley, K. M. Smithgall, J. M. Melack and K. Fang (2016). The fan of influence of streams and channel feedbacks to simulated land surface water and carbon dynamics. Water Resour. Res. doi:10.1002/2015WR018086

Shrestha P., M. Sulis, M. Masbou, S. Kollet, and C. Simmer (2014). A scale-consistent terrestrial systems modeling platform based on COSMO, CLM, and ParFlow. Mon. Weat. Rev., 142, 3466-3483.

Simoni, S., Zanotti, F., Bertoldi, G. and Rigon, R., (2008). Modelling the probability of occurrence of shallow landslides and channelized debris flows using GEOtop-FS. Hydrol. Process., 22, 532-545.

Šimůnek, J., N.J. Jarvis, M.T. van Genuchten, and A. Gärdenäs (2003), Review and comparison of models describing non-equilibrium and preferential flow and transport in the vadose zone, J Hydrol., 272, 14-35. 
Singha, K., Day-Lewis, F.D., Johnson, T., and Slater, L.D. (2014). Advances in interpretation of subsurface processes with time-lapse electrical imaging. Hydrol. Process., 29(6) 15491576, doi: 10.1002/hyp.10280

Siqueira, M., G. Katul, and A. Porporato (2009). Soil moisture feedbacks on convection triggers: The role of soil-plant hydrodynamics. J. Hydrometeorol., 10, 96-112.

Sivapalan, M. (2003). Process complexity at hillslope scale, process simplicity at the watershed scale: is there a connection? Hydrol. Process., 17, 1037-1041.

Sivapalan, M., Bloschl, G., Zhang, L., and Vertessy, R. (2003). Downward approach to hydrological prediction. Hydrol. Process., 17(11), 2101-2111.

Sivapalan, M., Savenije, H. H. G. and Blöschl, G. (2012), Socio-hydrology: A new science of people and water. Hydrol. Process., 26: 1270-1276. doi: 10.1002/hyp.8426

Sivapalan, M., M. Konar, V. Srinivasan, A. Chhatre, A. Wutich, C. A. Scott, J. L. Wescoat, and I. Rodríguez-Iturbe (2014), Socio-hydrology: Use-inspired water sustainability science for the Anthropocene, Earth's Future, 2, doi:10.1002/2013EF000164.

Skahill, B., J. S. Baggett, S. Frankenstein, and C W. Downer (2009). PEST compatible efficiency enhancements for Levenberg-Marquardt method based model independent calibration. Environ. Modell. Softw., 24, 517-529.

Slaughter, C. W., D. Marks, G. N. Flerchinger, S. S. VanVactor, and M. Burgess (2001). Thirty-five years of research data collection at the Reynolds Creek Experimental Watershed, Idaho, United States. Water Resour. Res., 37(11), 2819-2823.

Smith, J. A., (1992). Representation of basin scale in flood peak distribution. Water Resour. Res., 28(11): 2993-2999.

Srinivasan, V., E. F. Lambin, S. M. Gorelick, B. H. Thompson, and S. Rozelle (2012). The 1460 nature and causes of the global water crisis: Syndromes from a meta-analysis of coupled human-water studies. Water Resour. Res., 48, W10516, doi:10.1029/2011WR011087.

Steele-Dunne, S. C., M. M. Rutten, D. M. Krzeminska, M. Hausner, S. W. Tyler, J. Selker, T. A. Bogaard, and N. C. van de Giesen (2010). Feasibility of soil moisture estimation using passive distributed temperature sensing. Water Resour. Res., 46, W03534, doi:10.1029/2009WR008272.

Steinschneider S., Wi S. and Brown C. (2014), The integrated effects of climate and hydrologic uncertainty on future flood risk assessments, Hydrol. Process., doi: 10.1002/hyp.10409 
1461 Stephenson G, R., and R. A. Freeze (1974). Mathematical simulation of subsurface flow 1462 contributions to snowmelt and runoff, Reynolds Creek watershed, Idaho. Water Resour. 1463 Res., 10, 284-294.

1464 Sudicky E. A., J. P. Jones, Y.-J. Park, A. E. Brookfield and D. Colautti (2008). Simulating 1465 complex flow and transport dynamics in an integrated surface-subsurface modeling 1466 framework. Geosciences Journal, 12(2), 107-122.

1467 Sulis M., Paniconi C., Marrocu M., Huard D., Chaumont D. (2012). Hydrologic response to 1468 multimodel climate output using a physically based model of groundwater/surface water interactions. Water Resour. Res., 48, W12510, doi:10.1029/2012WR012

Swank W. T. and D. A. Crossley (1988). Forest Hydrology and Ecology at Coweeta, Springer-Verlag, New York.

Tague, C. L. (2009). Assessing climate change impacts on alpine stream-flow and vegetation water use: mining the linkages with subsurface hydrologic processes. Hydrol. Process., $23,1815-1819$.

Tague, C. L., and L. E. Band (2004). RHESSys: Regional Hydro-Ecologic Simulation System: An object-oriented approach to spatially distributed modeling of carbon, water, and nutrient cycling. Earth Interact., 8(19), 1-42.

Talbot, C. A., and F. L. Ogden (2008). A method for computing infiltration and redistribution in a discretized moisture content domain, Water Resour. Res., 44, W08453, doi:10.1029/2008WR006815.

Tocci, M. D., C. T. Kelley, and C. T. Miller (1997), Accurate and economical solution of the 1483 pressure-head form of Richards' equation by the method of lines, Adv. Wat. Resour., 20(1), $1-14$.

Troch, P. A., G. A. Carrillo, I. Heidbüchel, S. Rajagopal, M. Switanek, T. H. M. Volkmann and M. Yaeger (2008). Dealing with landscape heterogeneity in watershed hydrology: A review of recent progress toward new hydrological theory. Geography Compass, 3, 375392. doi: 10.1111/j.1749-8198.2008.00186.x

Tromp-van Meerveld, H. J., A. L. James, J. J. McDonnell, and N. E. Peters (2008). A reference data set of hillslope rainfall runoff response, Panola Mountain Research Watershed, United States. Water Resour. Res., 44, W06502, doi:10.1029/2007WR006299.

Tyree, M. T. (1997). The cohesion-tension theory of sap ascent: current controversies. Journal of Experimental Botany, 48 (315), 1753-1765.

Tyree, M. T. (2003). The ascent of water. Nature, 423, 923. 
1494 Uhlenbrook S, Seibert J, Leibundgut C, Rohde A. (1999). Prediction uncertainty of 1495 conceptual rainfall-runoff models caused by problems in identifying model parameters and structure. Hydrological Sciences Journal 44, 779-797.

van Roosmalen, L., T. O. Sonnenborg, and K. H. Jensen (2009). The impact of climate and land use change on the hydrology of a large-scale agricultural catchment, Water Resour. Res., 45, W00A15, doi:10.1029/2007WR006760.

VanderKwaak, J. E., and K. Loague (2001). Hydrologic-response simulations for the R-5 catchment with a comprehensive physics-based model. Water Resour. Res., 37(4), 9991013

Vinogradov Y., Semenova O., and Vinogradova T. (2011). An approach to the scaling problem in hydrological modelling: the deterministic modelling hydrological system. Hydrol. Process. 25, 1055-1073.

Vivoni E. R. (2012a). Spatial patterns, processes and predictions in ecohydrology: Integrating technologies to meet the challenge. Ecohydrol., 5(3), 235-241.

Vivoni, E. R. (2012b). Diagnosing seasonal vegetation impacts on evapotranspiration and its partitioning at the catchment scale during SMEX04-NAME. J. Hydrometeorol., 13, 16311638.

Vivoni, E. R., J. C. Rodriguez, and C. J. Watts (2010). On the spatiotemporal variability of soil moisture and evapotranspiration in a mountainous basin within the North American monsoon region. Water Resour. Res., 46, W02509, doi:10.1029/2009WR008240.

Vivoni, E. R., G. Mascaro, S. Mniszewski, P. Fasel, E. P. Springer, V. Y. Ivanov, and R. L. Bras (2011). Real-world hydrologic assessment of a fully-distributed hydrological model in a parallel computing environment, J. Hydrology, 409, 483-496.

Vivoni, E. R., Rango, A., Anderson, C. A., Pierini, N. A., Schreiner-McGraw, A., Saripalli, S., and Laliberte, A. S. (2014). Ecohydrology with unmanned aerial vehicles. Ecosphere, 5(10), art130.

Vrugt, J. A., C. G. H. Diks, H. V. Gupta, W. Bouten, and J. M. Verstraten (2005). Improved treatment of uncertainty in hydrologic modeling: Combining the strengths of global optimization and data assimilation. Water Resour. Res., 41, W01017, doi:10.1029/2004WR003059.

Vrugt, J. A., C. J. F. ter Braak, C. G. H. Diks, and G. Schoups (2013). Hydrologic data assimilation using particle Markov chain Monte Carlo simulation: Theory, concepts and applications. Adv. Water Resour., 51, 457-478. 
Wagener, T., M. Sivapalan, P. Troch, and R. Woods (2007). Catchment classification and hydrologic similarity. Geography Compass, 1(4), 901-931.

Wang, C., Q. Duan, W. Gong, A. Ye, Z. Di, and C. Miao (2014). An evaluation of adaptive surrogate modeling based optimization with two benchmark problems. Environ. Modell. Softw., 60, 167-179.

Wang, J., and R. L. Bras (2009). A model of surface heat fluxes based on the theory of maximum entropy production. Water Resour. Res., 45, W11422, doi:10.1029/2009WR007900.

Wang, J., and R. L. Bras (2010). An extremum solution of the Monin-Obukhov similarity equations. J. Atmospheric Sciences, 67, 485-499.

Weiler, M., and J. J. McDonnell (2004). Virtual experiments: a new approach for improving process conceptualization in hillslope hydrology. J. Hydrol., 285, 3-18.

Weill, S., A. Mazzia, M. Putti, and C. Paniconi (2011). Coupling water flow and solute transport into a physically-based surface-subsurface hydrological model. Adv. Water Resour., 34(1), 128-136.

Western A. W. and R. B. Grayson (1998). The Tarrawarra data set: soil moisture patterns, soil characteristics and hydrological flux measurements. Water Resour. Res., 34(10), 2765-2768.

White, D. D., Wutich, A. Y., Larson, K. L., Gober, P., Lant, T. and C. M. Senneville (2010). Credibility, salience, and legitimacy of boundary objects: Water managers' assessment of a simulation model in an immersive decision theater. Science and Public Policy, 37(3), 219232.

Wood, E. F., et al. (2011), Hyperresolution global land surface modeling: Meeting a grand challenge for monitoring Earth's terrestrial water, Water Resour. Res., 47, W05301, doi:10.1029/2010WR010090.

Woolhiser, D. A. (1996). Search for physically based runoff model - a hydrological El Dorado? J. Hydraulic Eng., 122(3), 122-129.

Xiang, T. T., Vivoni, E. R., and Gochis, D. J. (2014). Seasonal evolution of ecohydrological controls on land surface temperature over complex terrain. Water Resour. Res., 50(5), 3852-3874.

Yetemen, O., Istanbulluoglu, E. I., Flores-Cervantes, J. H., Vivoni, E. R., and Bras, R. L. (2015). Ecohydrologic role of solar radiation on landscape evolution. Water Resour. Res., 51(2), 1127-1157. 
Zacharias, S., et al. (2011). A network of terrestrial environmental observatories in Germany,

1561

Vadose Zone J., 10, 955-973.

1562

1563

1564 

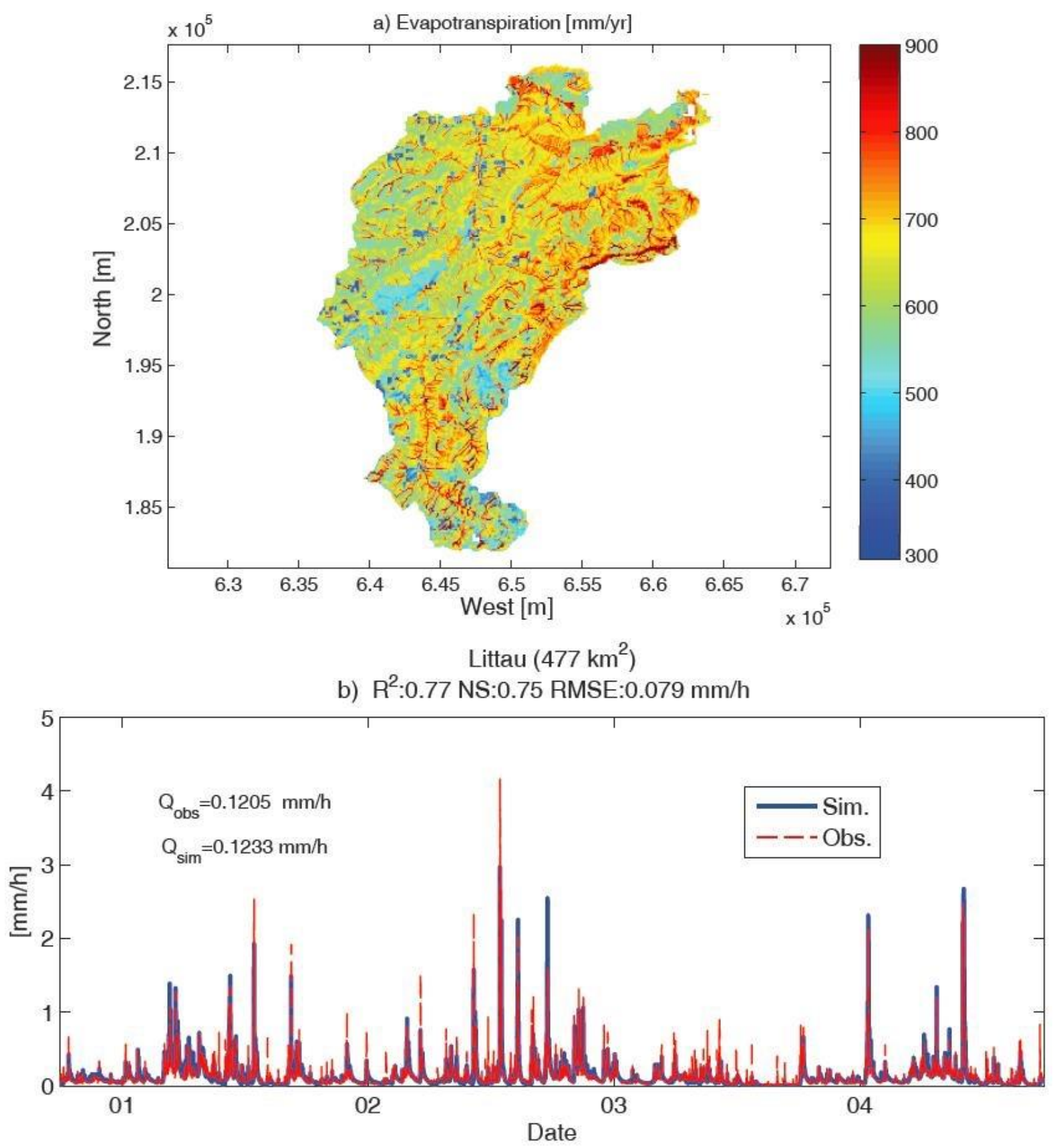

Date

1567 Figure 1. High-resolution $(\sim 100 \mathrm{~m})$ un-calibrated hydrological simulations with the process1568 based ecohydrological model Tethys-Chloris at the hourly time scale for the Kleine-Emme 1569 catchment $\left(477 \mathrm{~km}^{2}\right)$ (Switzerland) for the period $1^{\text {st }}$ October 2000 to $30^{\text {th }}$ September 2004. 1570 Spatially distributed forcing was provided by Meteo-Swiss and includes hourly station 1571 measurements of air temperature, wind speed, relative humidity, shortwave radiation and a 1572 gridded precipitation product RhiresD. Simulation results are presented for distributed 1573 evapotranspiration averaged over the four years (a) and streamflow at the catchment outlet 1574 (b). The match in water budget amount $\left(\mathrm{Q}_{\mathrm{obs}}\right.$ and $\mathrm{Q}_{\text {sim }}$ are the observed and simulated annual 
mean streamflow, respectively) and temporal dynamics (coefficient of determination $\mathrm{R}^{2}$, Nash-Sutcliffe efficiency, NS, and Root Mean Square Error, RMSE) between simulations and observations is very satisfactory, despite strong spatial heterogeneity in simulated evapotranspiration (not testable with current observations) and lack of calibration at the catchment scale.
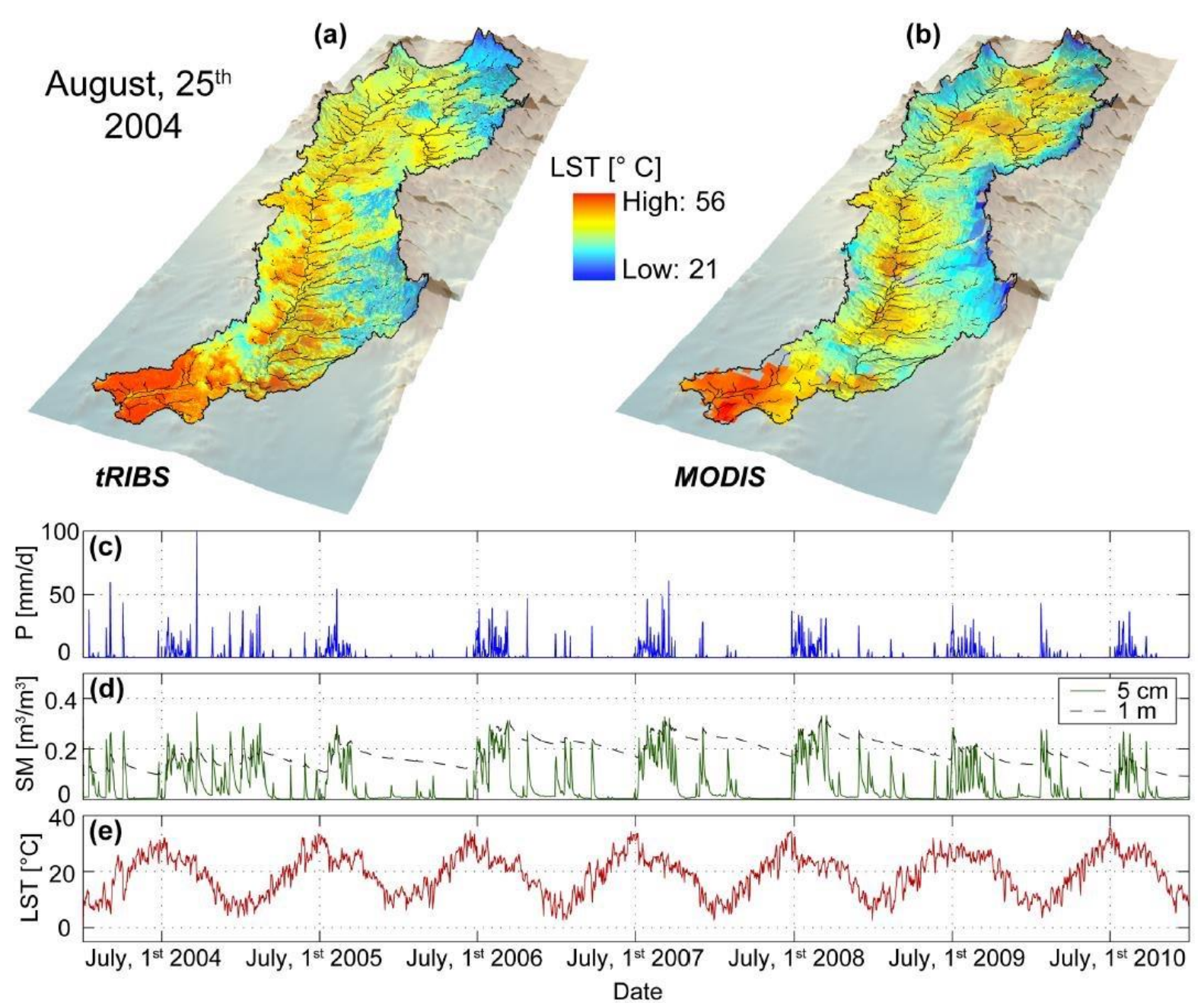

1582 Figure 2. High-resolution $(\sim 70 \mathrm{~m})$ hydrologic simulations with the tRIBS model in the Rio 1583 San Miguel basin $\left(3796 \mathrm{~km}^{2}\right)$, Mexico, from January, $1^{\text {st }} 2004$ to December $31^{\text {st }}, 2010$. 1584 Spatially-distributed hydrometeorological forcings were provided by hourly products from 1585 the North America Land Data Assimilation System (NLDAS), bias-corrected with ground observations. Hydrologic simulations were validated by comparing (i) time series of simulated and observed soil moisture (SM) and land surface temperature (LST) at nine distributed locations, and (ii) simulated SM and LST maps against remote sensing products from the 2D-Synthetic Aperture Radiometer (2D-STAR) and Moderate Resolution Imaging Spectroradiometer (MODIS), respectively. The LST maps simulated by tRIBS and observed by MODIS on August, 25th 2004 are presented in panels (a) and (b), respectively. A root mean square error of $4.0{ }^{\circ} \mathrm{C}$ and a correlation coefficient of 0.67 were obtained after 
resampling the simulated LST at the coarser MODIS resolution $(1 \mathrm{~km})$. The basin-averaged

1594 time series of (i) daily total P, (ii) daily average surface (top $5 \mathrm{~cm}$ ) and root zone (top $1 \mathrm{~m}$ ) 1595 SM, and (iii) daily average LST are reported in panels (c)-(e). Adapted from Mascaro et al. 1596 (2015).

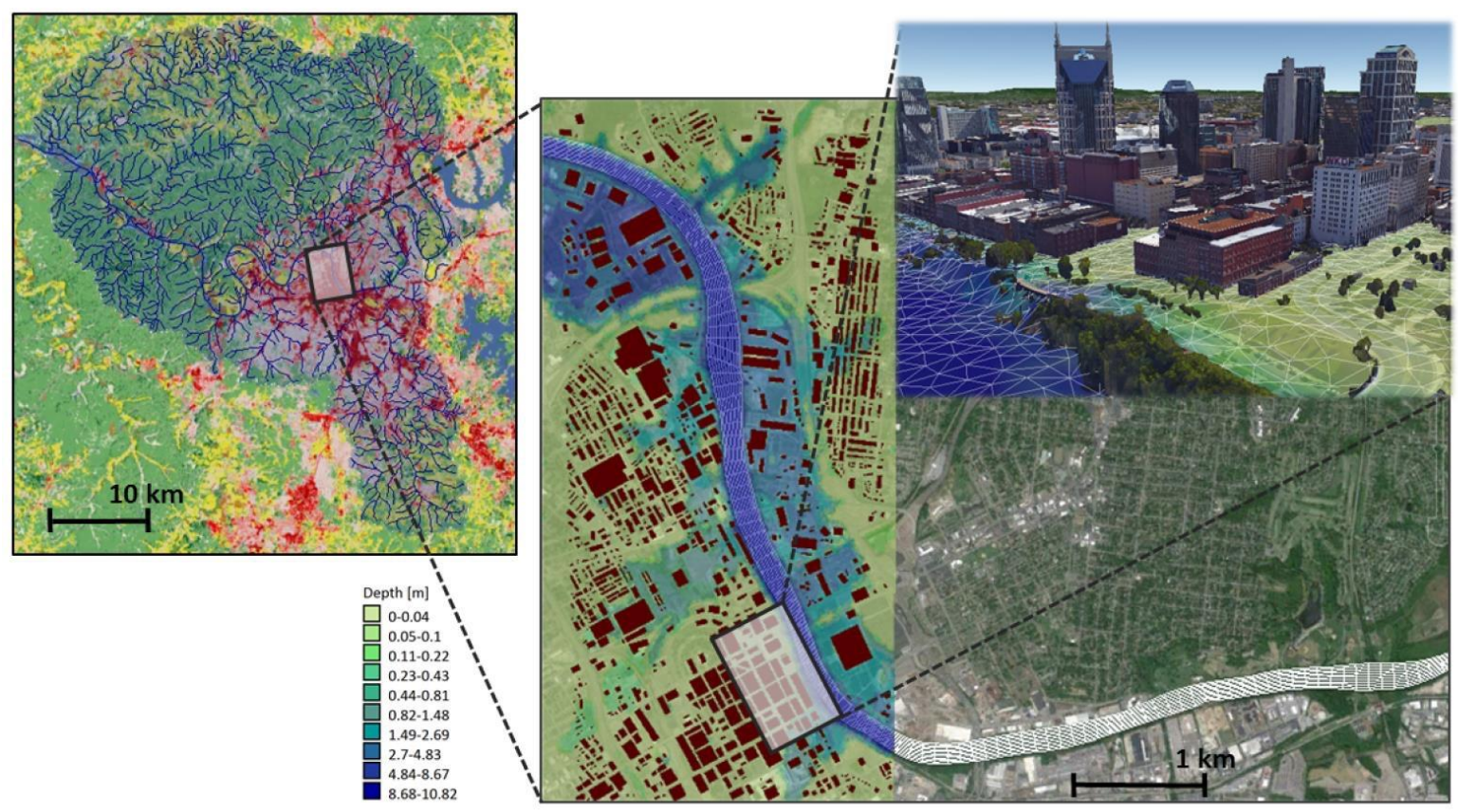

1599 Figure 3: A watershed scale - urban flood simulation with a coupled hydrologic and 1600 hydrodynamic model, tRIBS-VEGGIE-FEaST for a 'thousand-year' flood event in early May 1601 2010, Nashville (TN). A $\sim 1,000 \mathrm{~km}^{2}$ watershed (the left panel) contains naturally vegetated 1602 and agricultural areas, an urban center (over 500,000 buildings), contiguous channel and 1603 floodplain areas, and several upstream reservoirs. Seamless flood modeling for such a diverse 1604 domain requires a suite of interacting process-based models, ranging from spatially explicit 1605 rainfall-runoff partition to reservoir controls, and to hydraulic modeling that accounts for 1606 flood wave propagation and impediment by buildings. Multi-scale resolutions are necessary, 1607 ranging from few hundred meters for the watershed area, few decameters in the channel and 1608 floodplain, and few meters in the city downtown. The land-use and inundation maps (flow 1609 depths) are presented in the right panels, in which the downtown of Nashville with inundated 1610 water levels is highlighted. Satellite imagery and 3D buildings are based on satellite imagery 1611 processed by Google Earth. 